Prepared in cooperation with the Albuquerque Bernalillo County Water Utility Authority

\title{
Water-Level Data for the Albuquerque Basin and Adjacent Areas, Central New Mexico, Period of Record Through September 30, 2014
}

Data Series 963

Version 1.1, August 2021 



\section{Water-Level Data for the Albuquerque Basin and Adjacent Areas, Central New Mexico, Period of Record Through September 30, 2014}

By Joseph E. Beman

Prepared in cooperation with the Albuquerque Bernalillo County

Water Utility Authority

Data Series 963

(ver. 1.1, August 2021) 


\section{U.S. Geological Survey, Reston, Virginia First release: October 2015, online and in print Revised: August 2021 (ver. 1.1), online}

For more information on the USGS - the Federal source for science about the Earth, its natural and living resources, natural hazards, and the environment-visit https://www.usgs.gov or call 1-888-ASK-USGS.

For an overview of USGS information products, including maps, imagery, and publications, visit https://store.usgs.gov.

Any use of trade, firm, or product names is for descriptive purposes only and does not imply endorsement by the U.S. Government.

Although this information product, for the most part, is in the public domain, it also may contain copyrighted materials as noted in the text. Permission to reproduce copyrighted items must be secured from the copyright owner.

Suggested citation:

Beman, J.E., 2015, Water-level data for the Albuquerque Basin and adjacent areas, central New Mexico, period of record through September 30, 2014 (ver. 1.1, August 2021): U.S. Geological Survey Data Series 963, 42 p., https://doi. org/10.3133/ds963.

ISSN 2327-638X (online) 


\section{Contents}

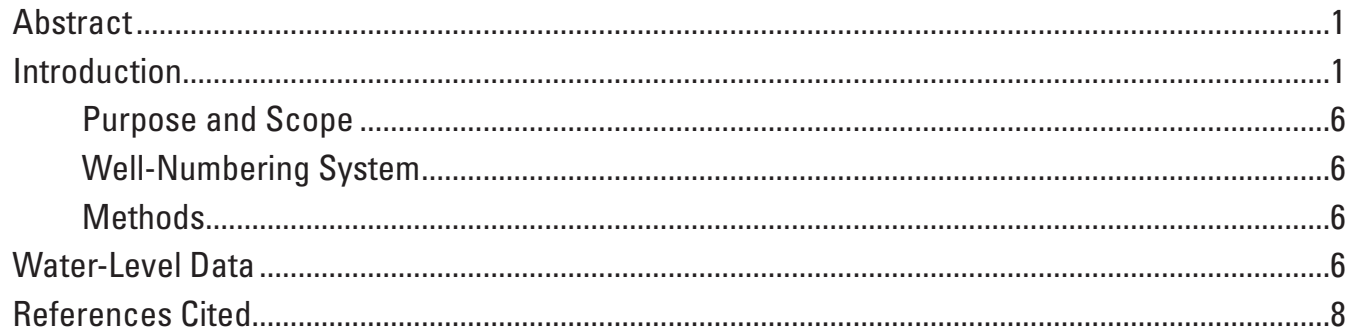

\section{Figures}

1. Map showing location of the study area and selected monitoring wells and piezometers in and near the Albuquerque Basin, central New Mexico.

2. Map showing location of selected monitoring wells and piezometers within the Albuquerque, New Mexico, metropolitan area 7

3. Diagram showing system for numbering wells and piezometers in New Mexico. .8

4. Graphs showing water-level data for selected wells and piezometers in the Albuquerque Basin, central New Mexico

\section{Tables}

1. Data from selected wells and piezometers for the Albuquerque Basin, central New Mexico

\section{Conversion Factors}

\begin{tabular}{|c|c|c|}
\hline Multiply & By & To obtain \\
\hline \multicolumn{3}{|c|}{ Length } \\
\hline foot $(\mathrm{ft})$ & 0.3048 & meter (m) \\
\hline mile (mi) & 1.609 & kilometer (km) \\
\hline \multicolumn{3}{|c|}{ Area } \\
\hline acre & 4,047 & square meter $\left(\mathrm{m}^{2}\right)$ \\
\hline
\end{tabular}

Vertical coordinate information is referenced to the National Geodetic Vertical Datum of 1929 (NGVD 29).

Water year is defined as beginning on 0 ctober 1 and continuing through September 30 of the following year. 



\title{
Water-Level Data for the Albuquerque Basin and Adjacent Areas, Central New Mexico, Period of Record Through September 30, 2014
}

\author{
By Joseph E. Beman
}

\section{Abstract}

The Albuquerque Basin, located in central New Mexico, is about 100 miles long and 25-40 miles wide. The basin is hydrologically defined as the extent of consolidated and unconsolidated deposits of Tertiary and Quaternary age that encompasses the structural Rio Grande Rift. Drinking-water supplies throughout the basin were obtained solely from groundwater resources until December 2008, when treatment and distribution of surface water from the Rio Grande through the San Juan-Chama Drinking Water Project began. A 20-percent population increase in the basin from 1990 to 2000 and a 22-percent population increase from 2000 to 2010 resulted in an increased demand for water.

An initial network of wells was established by the U.S. Geological Survey (USGS) in cooperation with the City of Albuquerque from April 1982 through September 1983 to monitor changes in groundwater levels throughout the basin. This network consisted of 6 wells with analog-to-digital recorders and 27 wells where water levels were measured monthly in 1983. The network currently (2014) consists of 125 wells and piezometers. (A piezometer is a specialized well open to a specific depth in the aquifer, often of small diameter and nested with other piezometers open to different depths.) The USGS, in cooperation with the Albuquerque Bernalillo County Water Utility Authority, currently (2014) measures and reports water levels from the 125 wells and piezometers in the network; this report presents water-level data collected by USGS personnel at those 125 sites through water year 2014 (October 1, 2013, to September 30, 2014).

\section{Introduction}

The Albuquerque Basin, located in central New Mexico, is about 100 miles long and 25-40 miles wide (fig. 1). The basin is defined as the extent of consolidated and unconsolidated deposits of Tertiary and Quaternary age that encompasses the structural Rio Grande Rift within the basin (Thorn and others, 1993). The study area extends from just upstream from Cochiti Lake south to San Acacia and from
Tijeras Canyon west to near the intersection of Interstate 40 and the Bernalillo-Cibola County line. The basin is approximately bisected by the southward-flowing Rio Grande, the only perennial stream extending through the length of the basin.

In 2000, the population of the Albuquerque Basin was about 690,000 (Bartolino and Cole, 2002). According to 2010 U.S. Census Bureau data, the 2010 population was about 840,000 (U.S. Census Bureau, 2011a; calculated as sum of population for census tract centers within basin). The majority of the population is concentrated within the city limits of Albuquerque, which had a population of 448,600 in 2000 (U.S. Census Bureau, 2001) and 545,852 in 2010 (U.S. Census Bureau, 2011b). The basin population increased about 20 percent from 1990 to 2000 (Thorn and others, 1993; Bartolino and Cole, 2002) and about 22 percent from 2000 to 2010 (U.S. Census Bureau, 2011a). Prior to 2008, demand for groundwater increased as population increased because drinking-water supplies throughout the Albuquerque Basin were obtained solely from groundwater sources. Drinkingwater supplies throughout the basin were obtained solely from groundwater resources until December 2008, when treatment and distribution of surface water from the Rio Grande through the San Juan-Chama Drinking Water Project began.

An initial network of wells was established by the U.S. Geological Survey (USGS) in cooperation with the City of Albuquerque from April 1982 through September 1983 to monitor changes in groundwater levels throughout the Albuquerque Basin. This network consisted of 6 wells with analog-to-digital recorders and 27 wells where water levels were measured monthly in 1983. Since the initial installation, additional wells and piezometers have been added to the network, and currently (2014), the network consists of 125 wells and piezometers (table 1). (A piezometer is a specialized well open to a specific depth in the aquifer, often of small diameter and nested with other piezometers open to different depths.) Of these wells and piezometers, 69 are equipped with continuous recording data loggers, and 56 are measured with a steel or electric tape semiannually, quarterly, or irregularly. During water year 2014, two wells (Estes 1 and 5; site numbers 9 and 10 in table 1) were reintroduced to the network when access permission from the property owner was reestablished. 

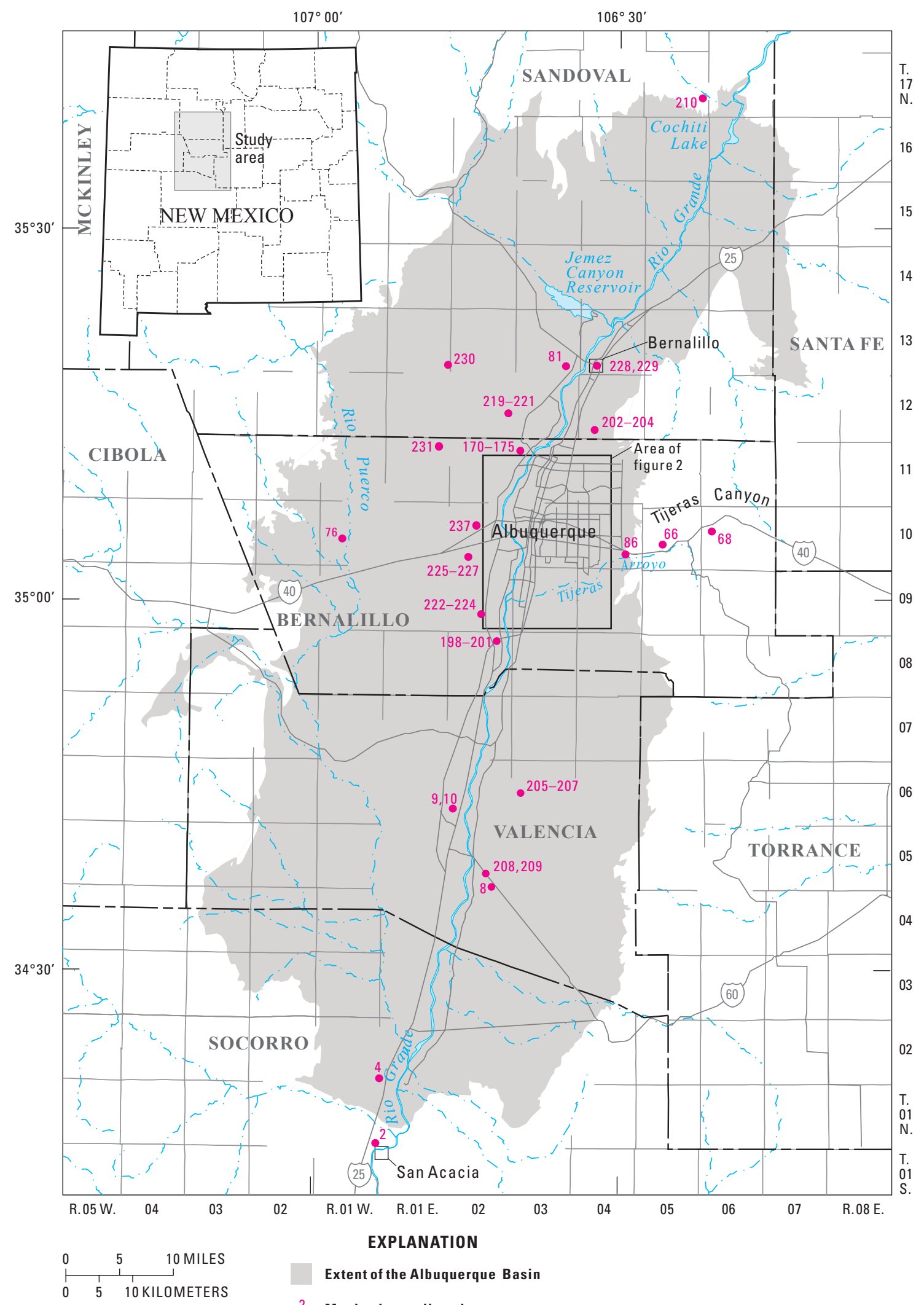

Extent of the Albuquerque Basin

-2 Monitoring well or piezometer-

Number refers to site number in

figure 4 and table 1

Figure 1. Location of the study area and selected monitoring wells and piezometers in and near the Albuquerque Basin, central New Mexico. 
Table 1. Data from selected wells and piezometers for the Albuquerque Basin, central New Mexico.

[USGS, U.S. Geological Survey; --, no data or not applicable. Discontinuity in numbering sequence is due to wells omitted from this report because of lack of recent data collection. Data from discontinued wells can be seen in previous USGS Open-File Reports and Data Series (Kues, 1987; Rankin, 1994, 1996, 1998, 1999, 2000; DeWees, 2001, 2002, 2003, 2006; Beman, 2007, 2008, 2009, 2011, 2012, 2013, 2014; Beman and Torres, 2010)]

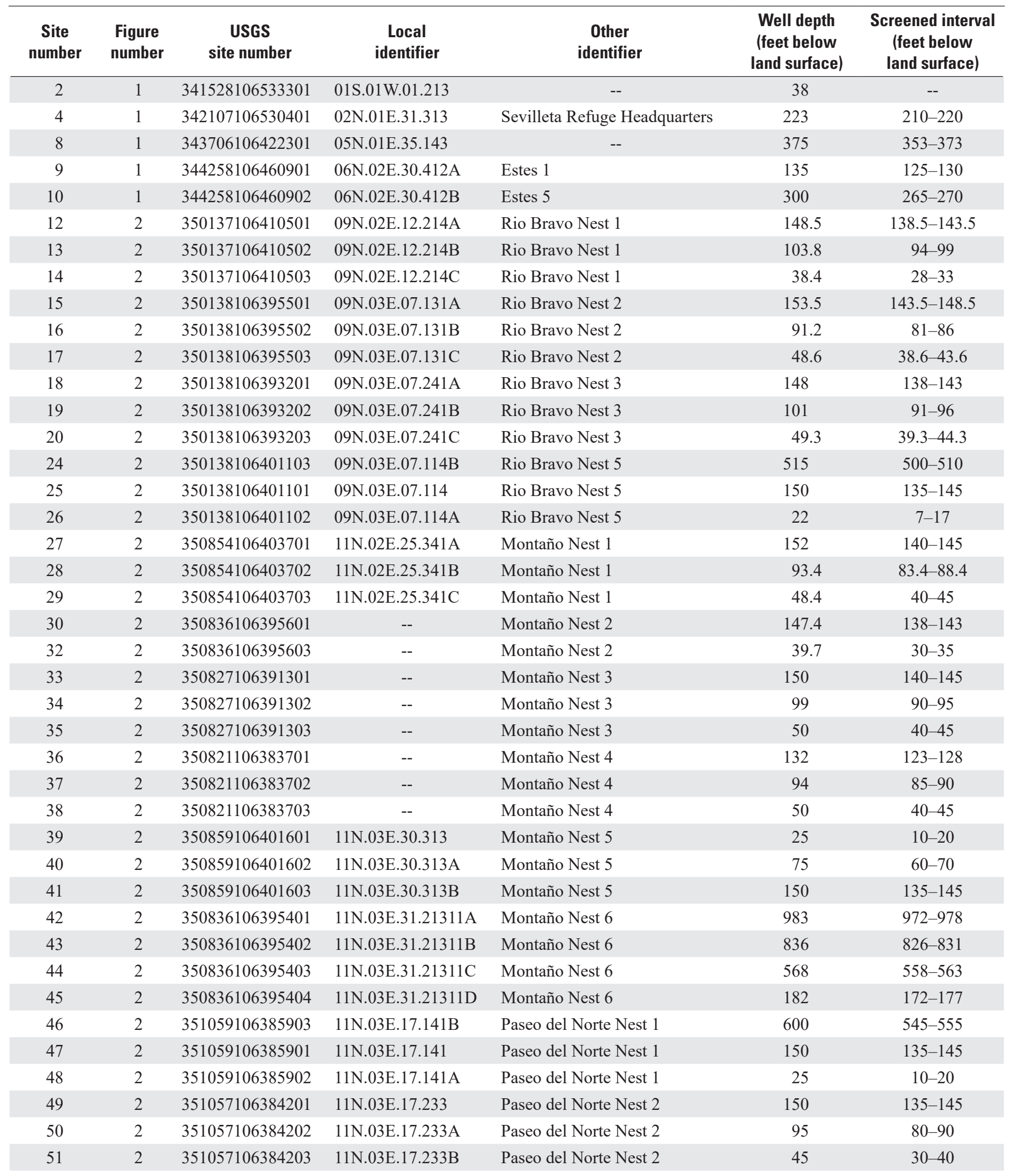


Table 1. Data from selected wells and piezometers for the Albuquerque Basin, central New Mexico._-Continued

[USGS, U.S. Geological Survey; --, no data or not applicable. Discontinuity in numbering sequence is due to wells omitted from this report because of lack of recent data collection. Data from discontinued wells can be seen in previous USGS Open-File Reports and Data Series (Kues, 1987; Rankin, 1994, 1996, 1998, 1999, 2000; DeWees, 2001, 2002, 2003, 2006; Beman, 2007, 2008, 2009, 2011, 2012, 2013, 2014; Beman and Torres, 2010)]

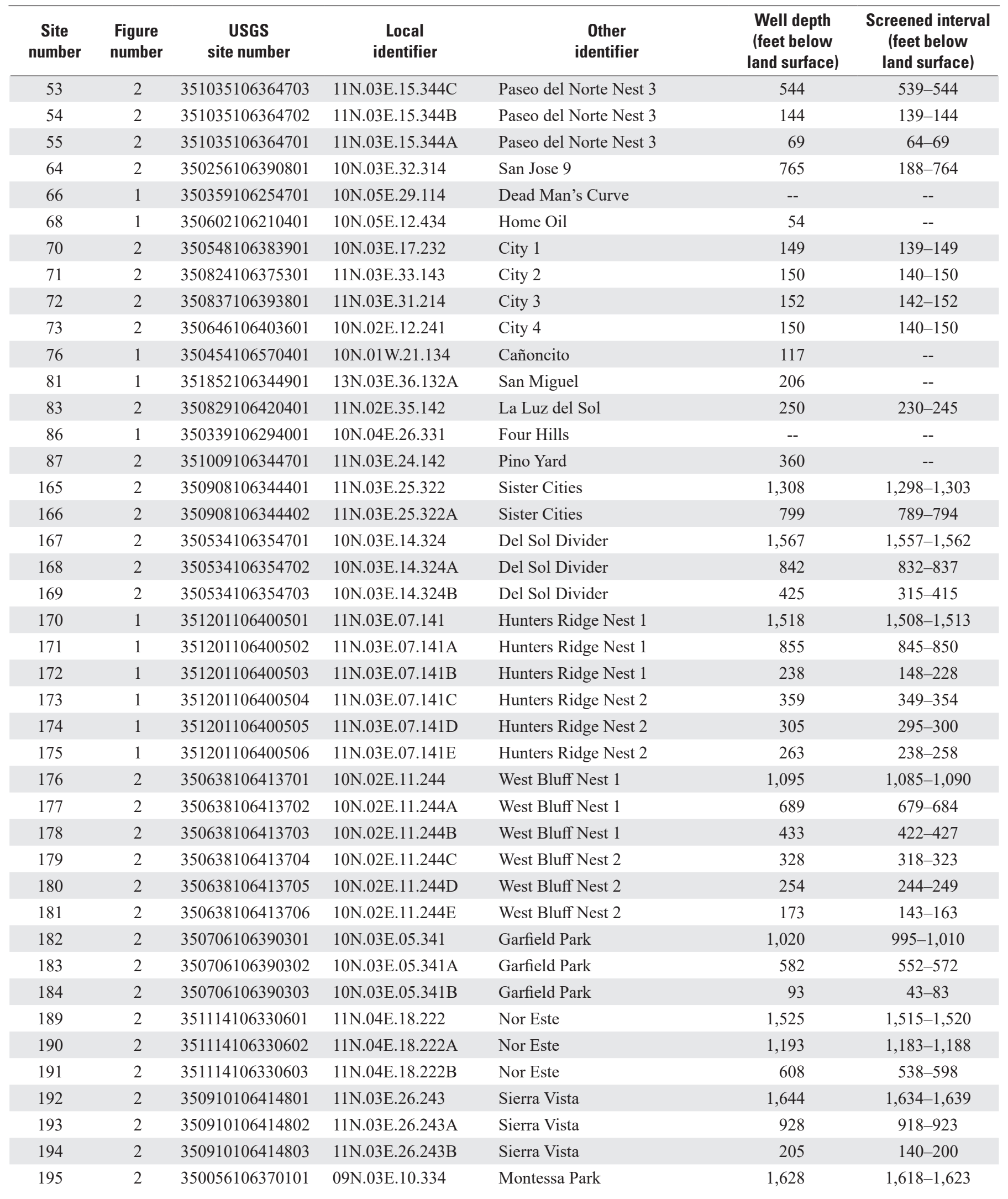


Table 1. Data from selected wells and piezometers for the Albuquerque Basin, central New Mexico.-Continued

[USGS, U.S. Geological Survey; --, no data or not applicable. Discontinuity in numbering sequence is due to wells omitted from this report because of lack of recent data collection. Data from discontinued wells can be seen in previous USGS Open-File Reports and Data Series (Kues, 1987; Rankin, 1994, 1996, 1998, 1999, 2000; DeWees, 2001, 2002, 2003, 2006; Beman, 2007, 2008, 2009, 2011, 2012, 2013, 2014; Beman and Torres, 2010)]

\begin{tabular}{|c|c|c|c|c|c|c|}
\hline $\begin{array}{c}\text { Site } \\
\text { number }\end{array}$ & $\begin{array}{l}\text { Figure } \\
\text { number }\end{array}$ & $\begin{array}{c}\text { USGS } \\
\text { site number }\end{array}$ & $\begin{array}{l}\text { Local } \\
\text { identifier }\end{array}$ & $\begin{array}{c}\text { Other } \\
\text { identifier }\end{array}$ & $\begin{array}{l}\text { Well depth } \\
\text { (feet below } \\
\text { land surface) }\end{array}$ & $\begin{array}{c}\text { Screened interval } \\
\text { (feet below } \\
\text { land surface) }\end{array}$ \\
\hline 196 & 2 & 350056106370102 & 09N.03E.10.334A & Montessa Park & 708 & $698-703$ \\
\hline 197 & 2 & 350056106370103 & 09N.03E.10.334B & Montessa Park & 330 & $260-320$ \\
\hline 198 & 1 & 345650106415901 & 08N.02E.02.413 & Isleta & 1,340 & $1,330-1,335$ \\
\hline 199 & 1 & 345650106415902 & 08N.02E.02.413A & Isleta & 815 & $805-810$ \\
\hline 201 & 1 & 345650106415904 & 08N.02E.02.413C & Isleta & 50 & $10-40$ \\
\hline 202 & 1 & 351357106323001 & 12N.04E.29.433 & Sandia Pueblo & 1,305 & $1,295-1,300$ \\
\hline 203 & 1 & 351357106323002 & 12N.04E.29.433A & Sandia Pueblo & 1,025 & $1,015-1,020$ \\
\hline 204 & 1 & 351357106323003 & 12N.04E.29.433B & Sandia Pueblo & 535 & $485-525$ \\
\hline 205 & 1 & 344431106393401 & 06N.03E.18.442 & Tomé & 1,200 & $1,185-1,195$ \\
\hline 209 & 1 & 343753106430602 & 05N.03E.28.411A & Nancy Lopez & 695 & 675-685 \\
\hline 210 & 1 & 354056106215801 & 17N.05E.24.344 & Dome Road & 1,295 & $1,280-1,290$ \\
\hline 211 & 2 & 350100106405701 & 09N.02E.12.433 & Rio Bravo Park & 595 & $585-590$ \\
\hline 212 & 2 & 350100106405702 & 09N.02E.12.433A & Rio Bravo Park & 210 & $200-205$ \\
\hline 213 & 2 & 345758106364001 & 09N.03E.34.231 & Mesa del Sol & 1,630 & $1,580-1,620$ \\
\hline 214 & 2 & 345758106364002 & 09N.03E.34.231A & Mesa del Sol & 1,015 & $990-1,010$ \\
\hline 215 & 2 & 345758106364003 & 09N.03E.34.231B & Mesa del Sol & 525 & $420-520$ \\
\hline 216 & 2 & 350653106311601 & 10N.04E.09.214 & Matheson Park & 1,520 & $1,460-1,500$ \\
\hline 217 & 2 & 350653106311602 & 10N.04E.09.214A & Matheson Park & 1,045 & $1,020-1,040$ \\
\hline 224 & 1 & 345842106443103 & 09N.02E.28.312B & Niese Road & 297 & $242-292$ \\
\hline 225 & 1 & 350244106450201 & 10N.02E.32.433 & Westgate Heights Park & 1,290 & $1,280-1,285$ \\
\hline 226 & 1 & 350244106450202 & 10N.02E.32.433A & Westgate Heights Park & 868 & $858-863$ \\
\hline 227 & 1 & 350244106450203 & 10N.02E.32.433B & Westgate Heights Park & 370 & $320-360$ \\
\hline 228 & 1 & 351821106333901 & 13N.04E.31.343 & Bernalillo & 1,190 & $1,175-1,185$ \\
\hline 229 & 1 & 351821106333902 & 13N.04E.31.343A & Bernalillo & 805 & 290-300 \\
\hline 230 & 1 & 352019106474801 & 13N.01E.24.313 & Phoenix Road & 1,625 & $1,600-1,620$ \\
\hline 231 & 1 & 351040106482801 & 11N.01E.14.342 & Paradise Road & 1,740 & $1,720-1,730$ \\
\hline 232 & 2 & 350545106335901 & 10N.04E.18.133A & Jerry Cline Park & 1,462 & $1,435-1,445$ \\
\hline 233 & 2 & 350545106335902 & 10N.04E.18.133B & Jerry Cline Park & 1,040 & $1,030-1,040$ \\
\hline 234 & 2 & 350545106335903 & 10N.04E.18.133C & Jerry Cline Park & 510 & $400-500$ \\
\hline 235 & 2 & 350307106410601 & 10N.02E.36.321A & Armijo & 1,623 & $1,593-1,613$ \\
\hline 236 & 2 & 350307106410602 & 10N.02E.36.321B & Armijo & 1,025 & $995-1,015$ \\
\hline 237 & 1 & 350552106444601 & -- & Arroyo Vista & 1,424 & $520-1,424$ \\
\hline
\end{tabular}


The USGS, in cooperation with the Albuquerque Bernalillo County Water Utility Authority (ABCWUA), currently (2014) measures and reports water levels from the 125 wells and piezometers in the network (table 1). Monitoring-well locations within the basin and adjacent areas are shown in figure 1, and those within the Albuquerque metropolitan area are shown in figure 2.

\section{Purpose and Scope}

The purpose of this report is to present an annual update of water-level data collected from the Albuquerque Basin well network during the 2014 water year (October 1, 2013, to September 30, 2014). Water-level data collected from the Albuquerque Basin and adjacent areas for the period of record through September 30, 2014, are presented. Water-level data that were collected from wells previously but not during the 2014 water year can be found in previous versions of this report (Kues, 1987; Rankin, 1994, 1996, 1998, 1999, 2000; DeWees, 2001, 2002, 2003, 2006; Beman, 2007, 2008, 2009, 2011, 2012, 2013, 2014; Beman and Torres, 2010). Data from wells appearing in the current version but not in the previous year were reintroduced after access problems to the site were resolved.

\section{Well-Numbering System}

The system of numbering wells and piezometers in New Mexico is based on the common subdivision of public lands into sections (fig. 3). Each well number, in addition to designating the well, locates the position to the nearest 10 -acre tract in the land network. This number (referred to as "local identifier" in table 1) is divided into four segments. The first segment denotes the township ("T.") north or south of the New Mexico base line, the second denotes the range ("R.") east or west of the New Mexico primary meridian, and the third denotes the section. The fourth segment of the well number, which consists of three digits, denotes the 160-, 40-, and 10 -acre tracts in which the well is located. Each section is divided into quarters - numbered 1, 2, 3, and 4-for the northwest, northeast, southwest, and southeast quarters, respectively. The first digit of the fourth segment gives the quarter section, which is a tract of 160 acres. Each quarter section is then subdivided into four 40 -acre tracts numbered in the same manner, and the second digit denotes the 40 -acre tract. Finally, each 40 -acre tract is further subdivided into four 10 -acre tracts, and the third digit denotes the 10 -acre tract. The fourth segment of the well number can further denote subdivisions of the 10 -acre tract by including more than three digits; each additional digit further subdivides the tract by quarters in the same manner as shown in figure 3. Letters A, B, C, and so on are added to the end of the last segment of the well number to designate the second, third, fourth, and succeeding wells in the same tract. For example, well 09N.03E.07.131A is the first subsequent well in the northwest quarter (NW 1/4) of the southwest quarter (SW 1/4) of the northwest quarter (NW 1/4) of section 7, T. 09 N., R. 03 E. (fig. 3).

\section{Methods}

Electric and steel tapes are used to collect water-level measurements at all wells and piezometers. Fifty-one of the sites $(2,4,8-10,12-20,24-30,32-41,46-51,53-55$, $68,70-73,76,81,83,86,87$, and 237) are measured semiannually, and two of the sites (230 and 231) are measured quarterly. At 69 of the sites $(42-45,64,66,165-184,189-221$, 225-229, and 232-236), pressure transducers and data loggers are used to collect hourly water-level data. The transducers and data loggers were removed from sites 222-224, but periodic measurements continue; the equipment may be redeployed to these piezometers after repairs are made to equipment housing.

\section{Water-Level Data}

Data for the 125 wells and piezometers in the network include USGS site number, number of the figure on which the well location is shown, local identifier, other identifier (if applicable), well depth, and screened interval (table 1). Hydrographs presenting water-level data collected by the USGS include depth to water, in feet below land surface, and hydraulic head, expressed as altitude in feet above the National Geodetic Vertical Datum of 1929 (NGVD 29) (fig. 4, at back of report). Data in hydrographs from wells that have continuous recorders are shown by solid lines that represent continuous data (fig. 4). In hydrographs that present data from periodically measured wells, dashed lines connect symbols ("+") that represent the periodic measurements (fig. 4). In hydrographs showing periodically measured piezometers that are nested (more than one trace per graph), the symbols were removed to make the hydrograph easier to read (fig. 4). There are two hydrographs presenting data for sites 42-45 and for sites 222-224: one showing periodic water-level measurements and one showing continuous data (fig. 4). Data gaps are present in some of the hydrographs; these gaps may be caused by, but are not limited to, equipment malfunction or spurious data. 


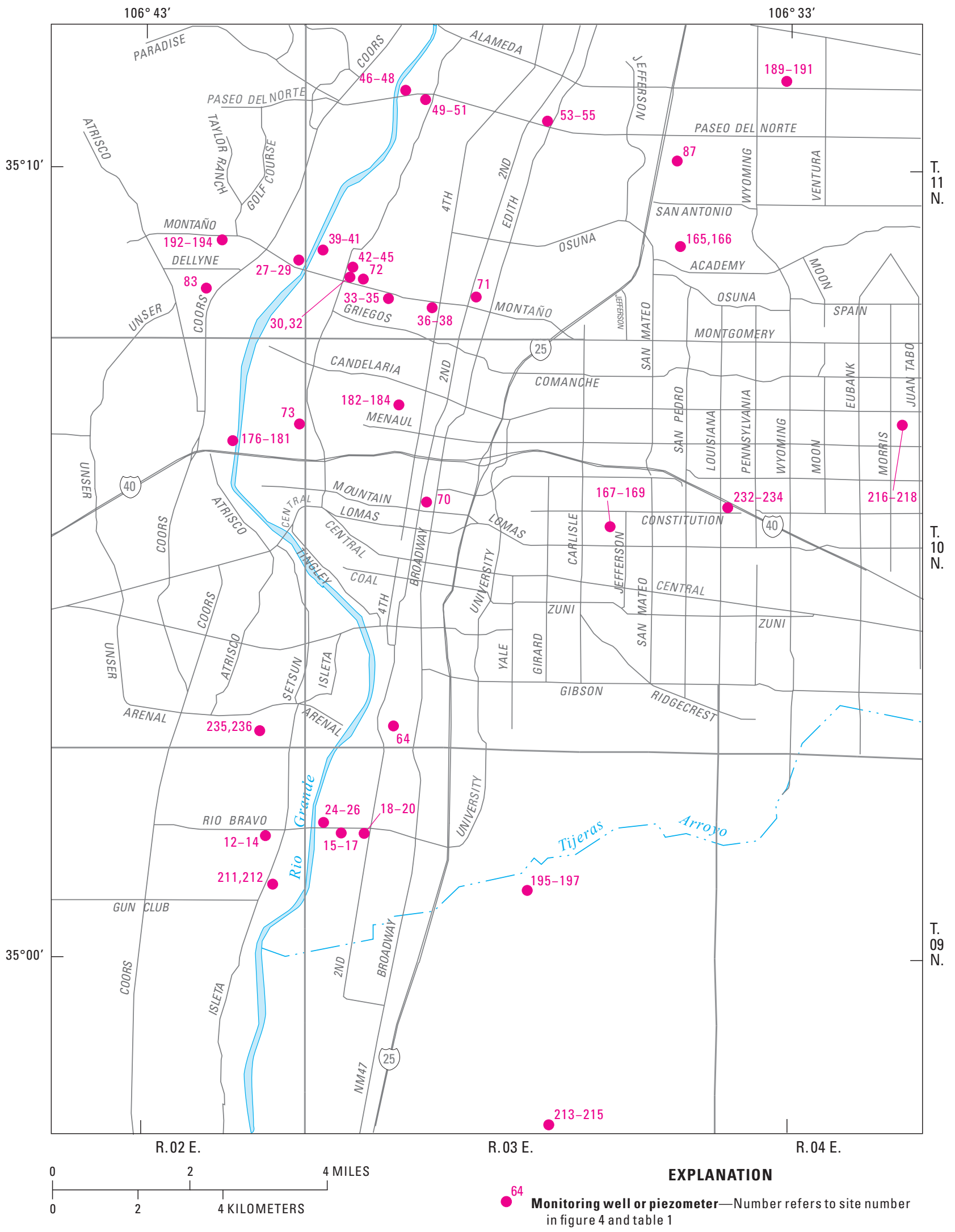

Figure 2. Location of selected monitoring wells and piezometers within the Albuquerque, New Mexico, metropolitan area. 


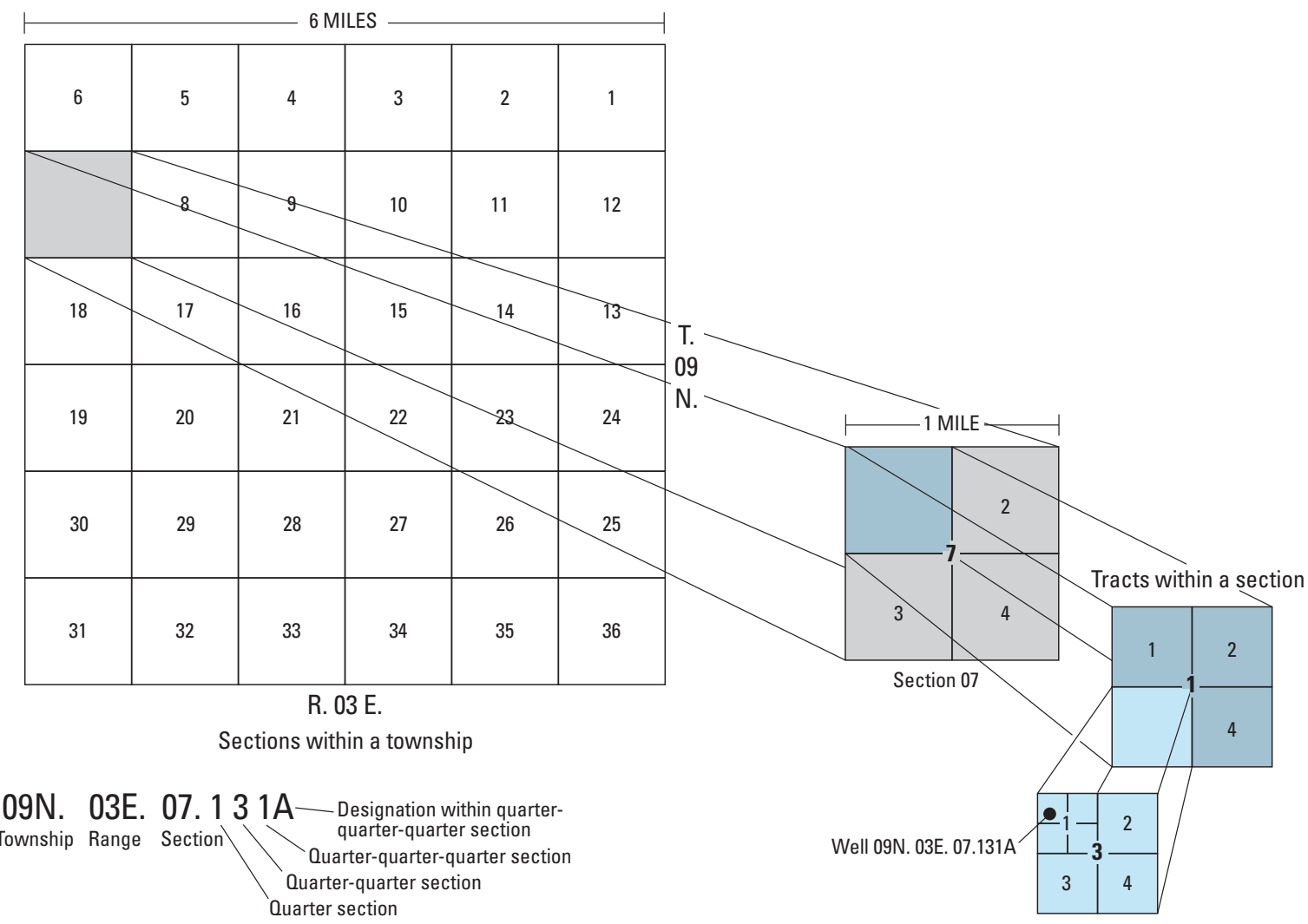

Figure 3. Showing system for numbering wells and piezometers in New Mexico.

\section{References Cited}

Bartolino, J.R., and Cole, J.C., 2002, Ground-water resources of the Middle Rio Grande Basin, New Mexico: U.S. Geological Survey Circular 1222, 132 p. [Also available at http://pubs. usgs.gov/circ/2002/circ1222/.]

Beman, J.E., 2007, Water-level data for the Albuquerque Basin and adjacent areas, central New Mexico, period of record through September 30, 2006: U.S. Geological Survey OpenFile Report 2007-1273, 34 p. [Also available at http://pubs. usgs.gov/of/2007/1273/.]

Beman, J.E., 2008, Water-level data for the Albuquerque Basin and adjacent areas, central New Mexico, period of record through September 30, 2007: U.S. Geological Survey OpenFile Report 2008-1255, 32 p. [Also available at http://pubs. usgs.gov/of/2008/1255/.]

Beman, J.E., 2009, Water-level data for the Albuquerque Basin and adjacent areas, central New Mexico, period of record through September 30, 2008: U.S. Geological Survey OpenFile Report 2009-1125, 37 p. [Also available at http://pubs. usgs.gov/of/2009/1125/.]
Beman, J.E., 2011, Water-level data for the Albuquerque Basin and adjacent areas, central New Mexico, period of record through September 30, 2010: U.S. Geological Survey Data Series 623, 28 p. [Also available at http:// pubs.usgs.gov/ds/623/.]

Beman, J.E., 2012, Water-level data for the Albuquerque Basin and adjacent areas, central New Mexico, period of record through September 30, 2011: U.S. Geological Survey Data Series 714, 29 p. [Also available at http:// pubs.usgs.gov/ds/714/.]

Beman, J.E., 2013, Water-level data for the Albuquerque Basin and adjacent areas, central New Mexico, period of record through September 30, 2012: U.S. Geological Survey Data Series 790, 28 p. [Also available at http:// pubs.usgs.gov/ds/790/.]

Beman, J.E., 2014, Water-level data for the Albuquerque Basin and adjacent areas, central New Mexico, period of record through September 30, 2013: U.S. Geological Survey Data Series 873, 40 p. [Also available at http:// pubs.usgs.gov/ds/873/.] 
Beman, J.E., and Torres, L.T., 2010, Water-level data for the Albuquerque Basin and adjacent areas, central New Mexico, period of record through September 30, 2009: U.S. Geological Survey Open-File Report 2010-1228, 31 p. [Also available at http://pubs.usgs.gov/of/2010/1228/.]

DeWees, R.K., 2001, Water-level data for the Albuquerque Basin and adjacent areas, central New Mexico, period of record through 2000: U.S. Geological Survey Open-File Report 2001-184, 62 p. [Also available at http://pubs. er.usgs.gov/publication/ofr01184.]

DeWees, R.K., 2002, Water-level data for the Albuquerque Basin and adjacent areas, central New Mexico, period of record through 2001: U.S. Geological Survey Open-File Report 2002-312, 41 p. [Also available at http://pubs. er.usgs.gov/publication/ofr02312.]

DeWees, R.K., 2003, Water-level data for the Albuquerque Basin and adjacent areas, central New Mexico, period of record through 2002: U.S. Geological Survey Open-File Report 2003-321, 41 p. [Also available at http://pubs. er.usgs.gov/publication/ofr03321.]

DeWees, R.K., 2006, Water-level data for the Albuquerque Basin and adjacent areas, central New Mexico, period of record through 2004: U.S. Geological Survey Open-File Report 2006-1281, 40 p. [Also available at http://pubs.usgs. gov/of/2006/1281/.]

Kues, G.E., 1987, Ground-water-level data for the Albuquerque-Belen Basin, New Mexico, through water year 1985: U.S. Geological Survey Open-File Report 87-116, 51 p. [Also available at http://pubs.er.usgs.gov/publication/ ofr87116.]

Rankin, D.R., 1994, Water-level data for the Albuquerque Basin, New Mexico, October 1, 1986, through September 30, 1990: U.S. Geological Survey Open-File Report 94-349, 29 p. [Also available at http://pubs.er.usgs.gov/ publication/ofr94349.]
Rankin, D.R., 1996, Water-level data for the Albuquerque Basin, New Mexico, period of record through September 30, 1995: U.S. Geological Survey Open-File Report 96-664A, 28 p. [Also available at http://pubs.er.usgs.gov/ publication/ofr96664A.]

Rankin, D.R., 1998, Water-level data for the Albuquerque Basin, central New Mexico, period of record through 1997: U.S. Geological Survey Open-File Report 98-408, 28 p. [Also available at http://pubs.er.usgs.gov/publication/ ofr98408.]

Rankin, D.R., 1999, Water-level data for the Albuquerque Basin and adjacent areas, New Mexico, period of record through 1998: U.S. Geological Survey Open-File Report 99-269, 27 p. [Also available at http://pubs.er.usgs.gov/ publication/ofr99269.]

Rankin, D.R., 2000, Water-level data for the Albuquerque Basin and adjacent areas, central New Mexico, period of record through 1999: U.S. Geological Survey Open-File Report 2000-231, 62 p. [Also available at http://pubs. er.usgs.gov/publication/ofr00231.]

Thorn, C.R., McAda, D.P., and Kernodle, J.M., 1993, Geohydrologic framework and hydrologic conditions in the Albuquerque Basin, central New Mexico: U.S. Geological Survey Water-Resources Investigations Report 93-4149, 106 p. [Also available at http://pubs.er.usgs.gov/publication/ wri934149.]

U.S. Census Bureau, 2001, State and county quickfacts: Accessed July 15, 2002, at http://quickfacts.census.gov.

U.S. Census Bureau, 2011a, 2010 census centers of population by census tract, updated March 12, 2013: Accessed April 18, 2013, at http:/www.census.gov/geo/reference/ centersofpop.html.

U.S. Census Bureau, 2011b, State and county quickfacts for Albuquerque (city), New Mexico: Accessed April 18, 2013, at http://quickfacts.census.gov/qfd/states/35/3502000.html. 

Figure $4 \quad 11$

Figure 4 


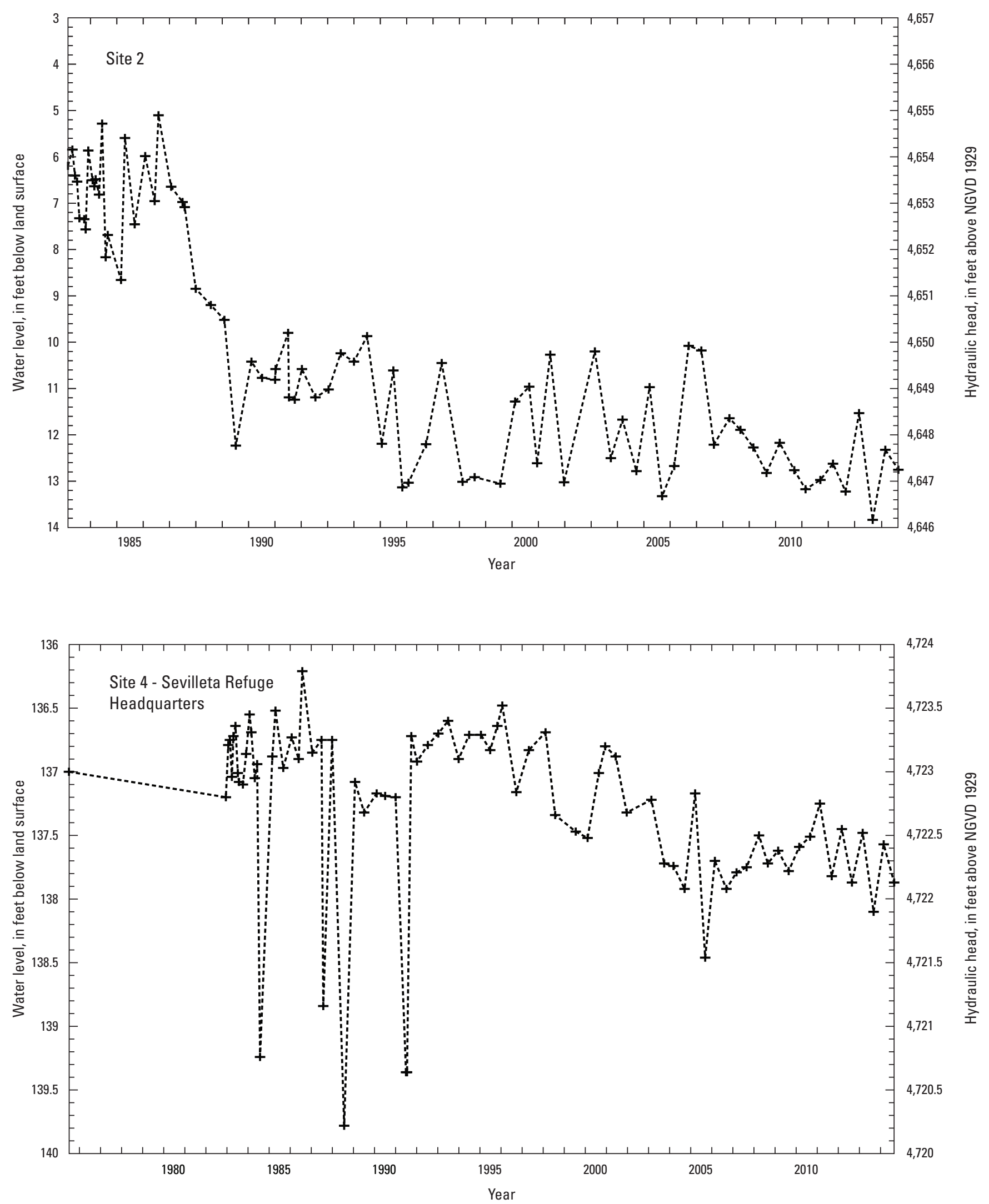

Figure 4. Water-level data for selected wells and piezometers in the Albuquerque Basin, central New Mexico (NGVD 29, National Geodetic Vertical Datum of 1929). 

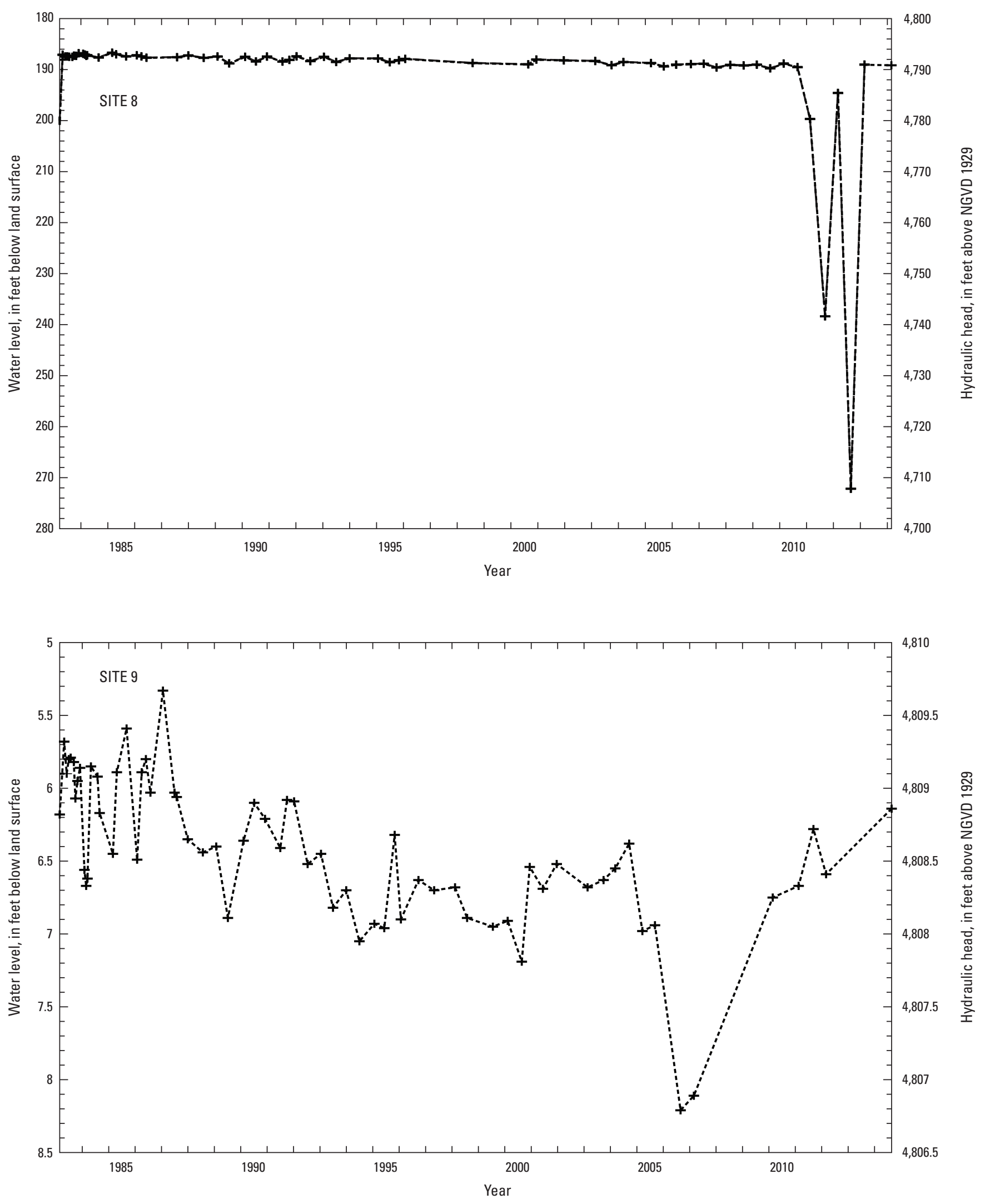

Figure 4. Water-level data for selected wells and piezometers in the Albuquerque Basin, central New Mexico (NGVD 29, National Geodetic Vertical Datum of 1929).-Continued 

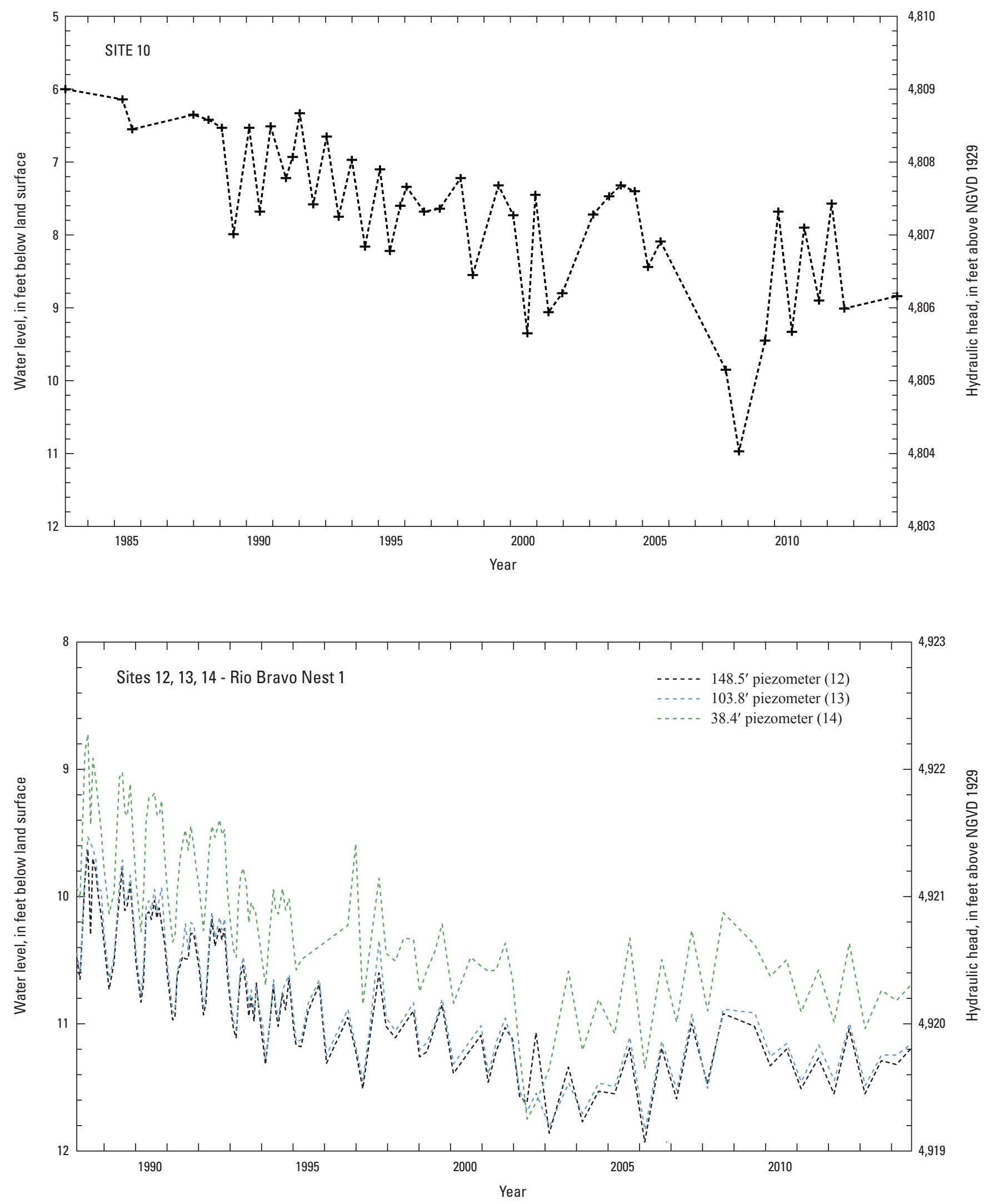

Figure 4. Water-level data for selected wells and piezometers in the Albuquerque Basin, central New Mexico (NGVD 29, National Geodetic Vertical Datum of 1929).-Continued 

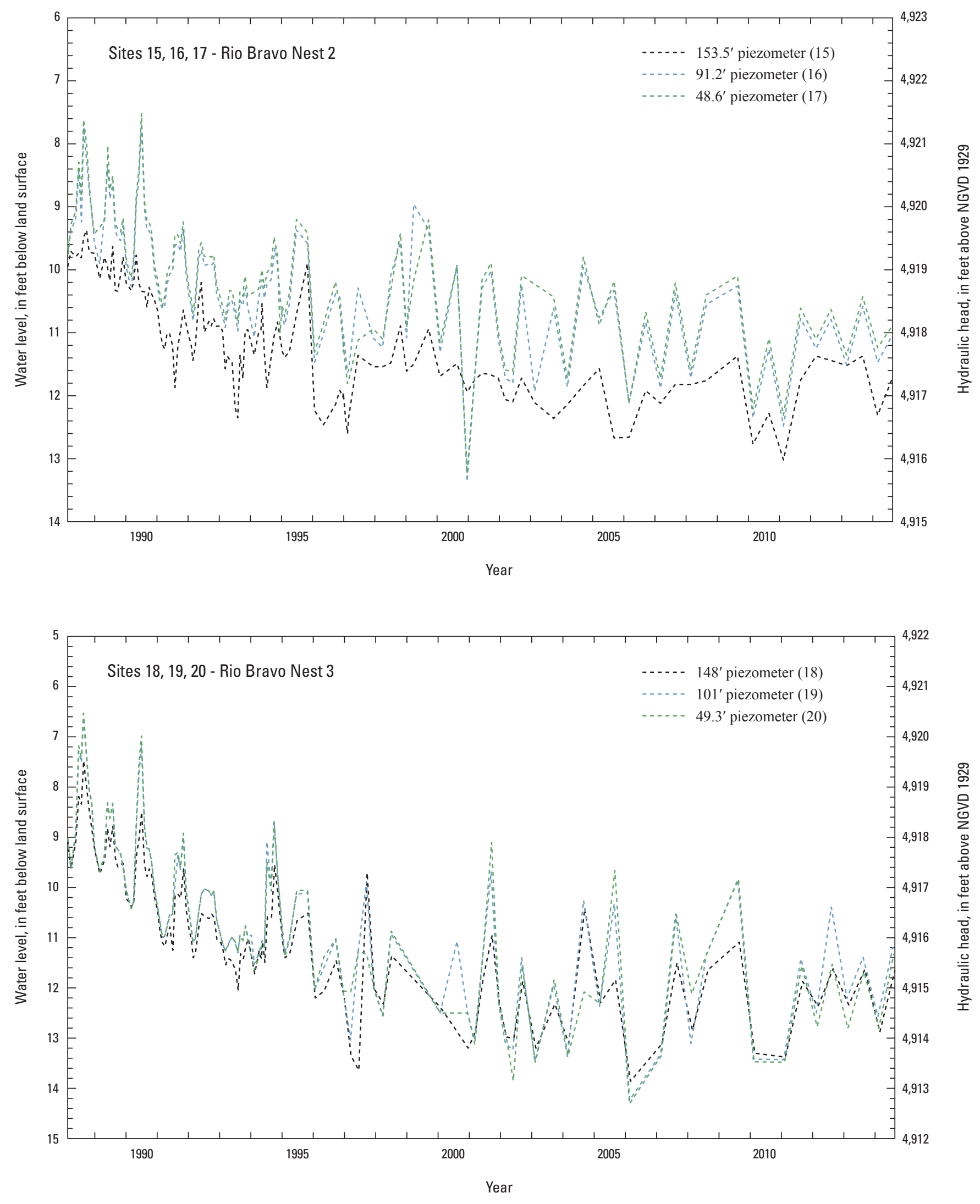

Figure 4. Water-level data for selected wells and piezometers in the Albuquerque Basin, central New Mexico (NGVD 29, National Geodetic Vertical Datum of 1929)._-Continued 

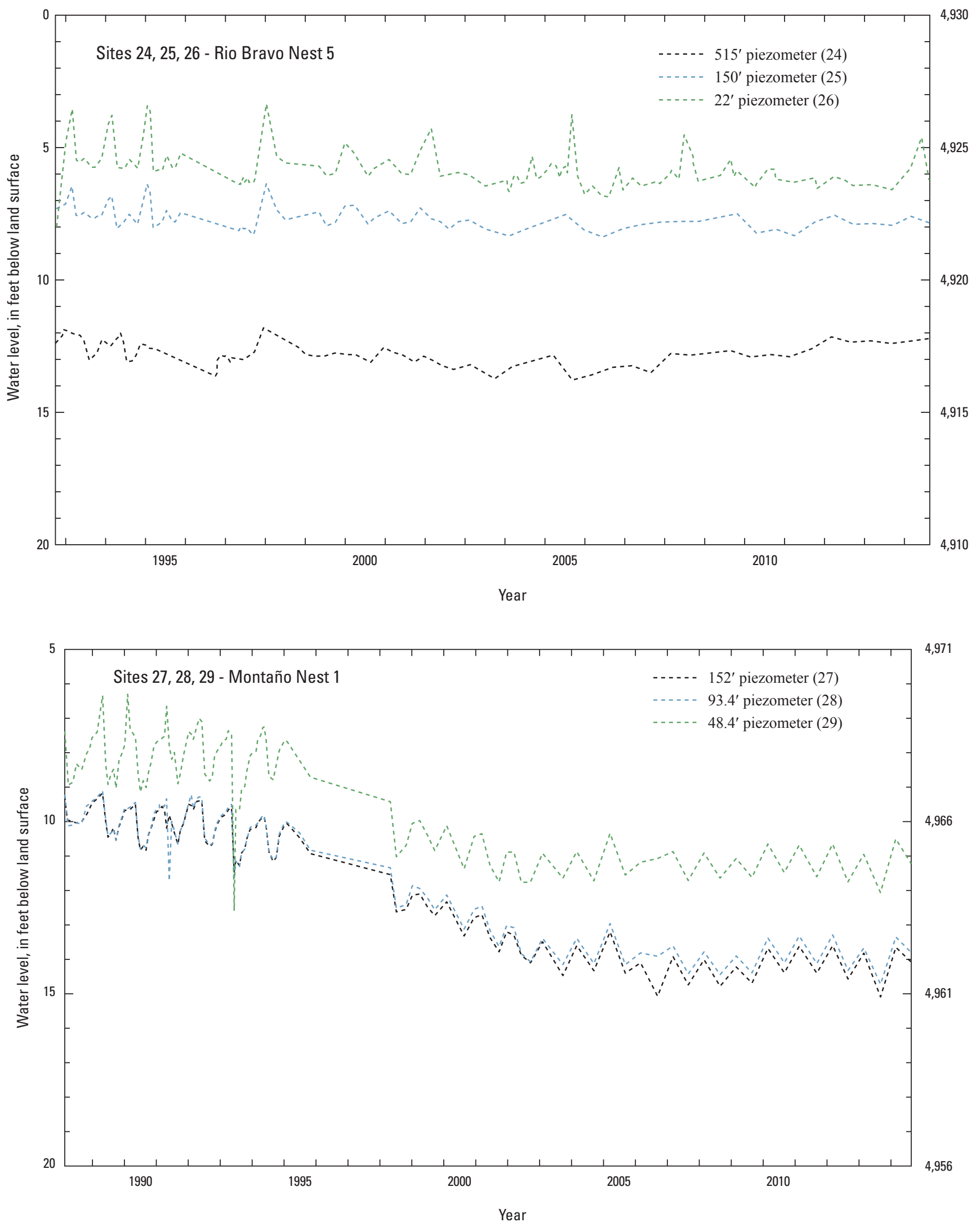

Figure 4. Water-level data for selected wells and piezometers in the Albuquerque Basin, central New Mexico (NGVD 29, National Geodetic Vertical Datum of 1929).-Continued 

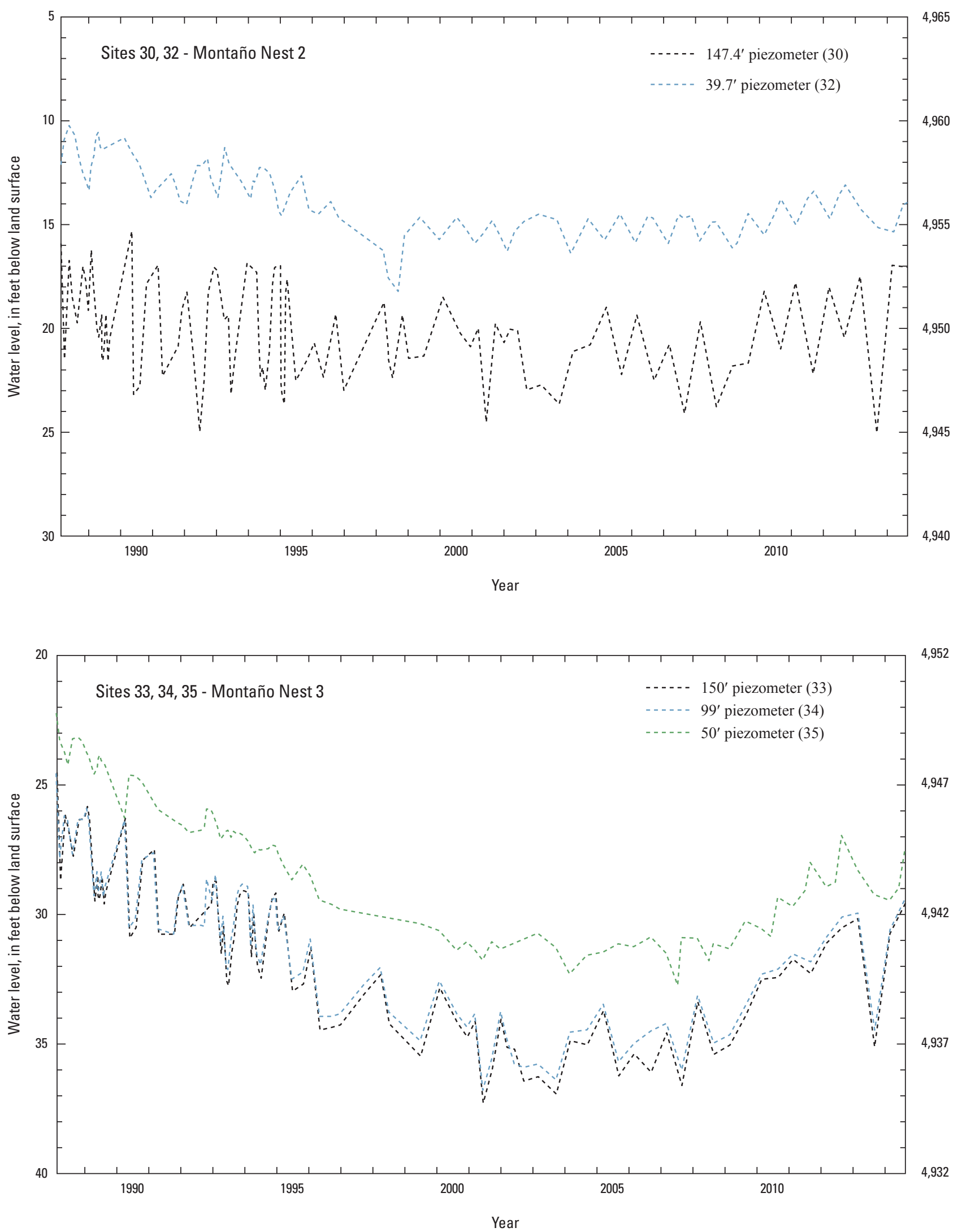

Figure 4. Water-level data for selected wells and piezometers in the Albuquerque Basin, central New Mexico (NGVD 29, National Geodetic Vertical Datum of 1929).-Continued 

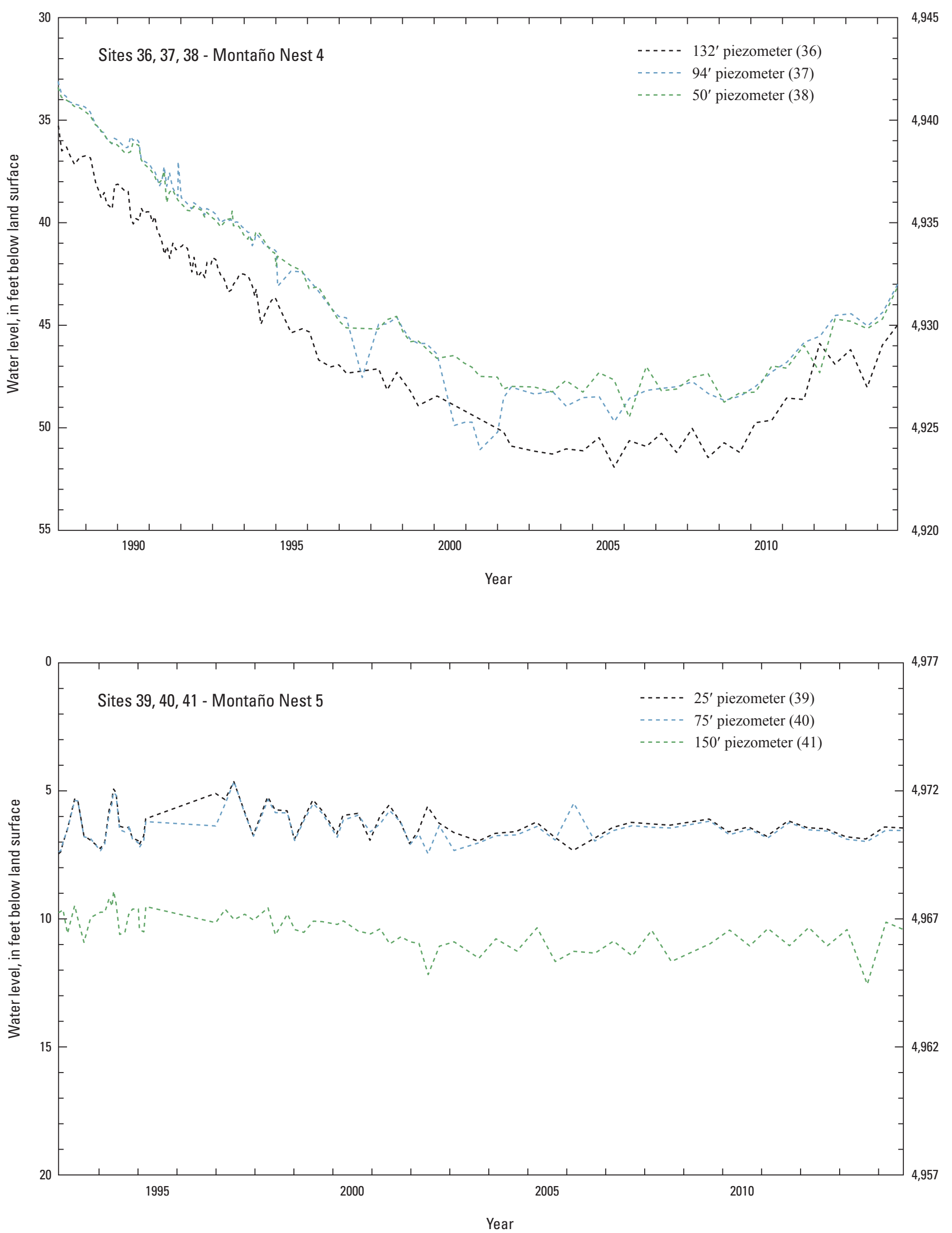

Figure 4. Water-level data for selected wells and piezometers in the Albuquerque Basin, central New Mexico (NGVD 29, National Geodetic Vertical Datum of 1929).-Continued 

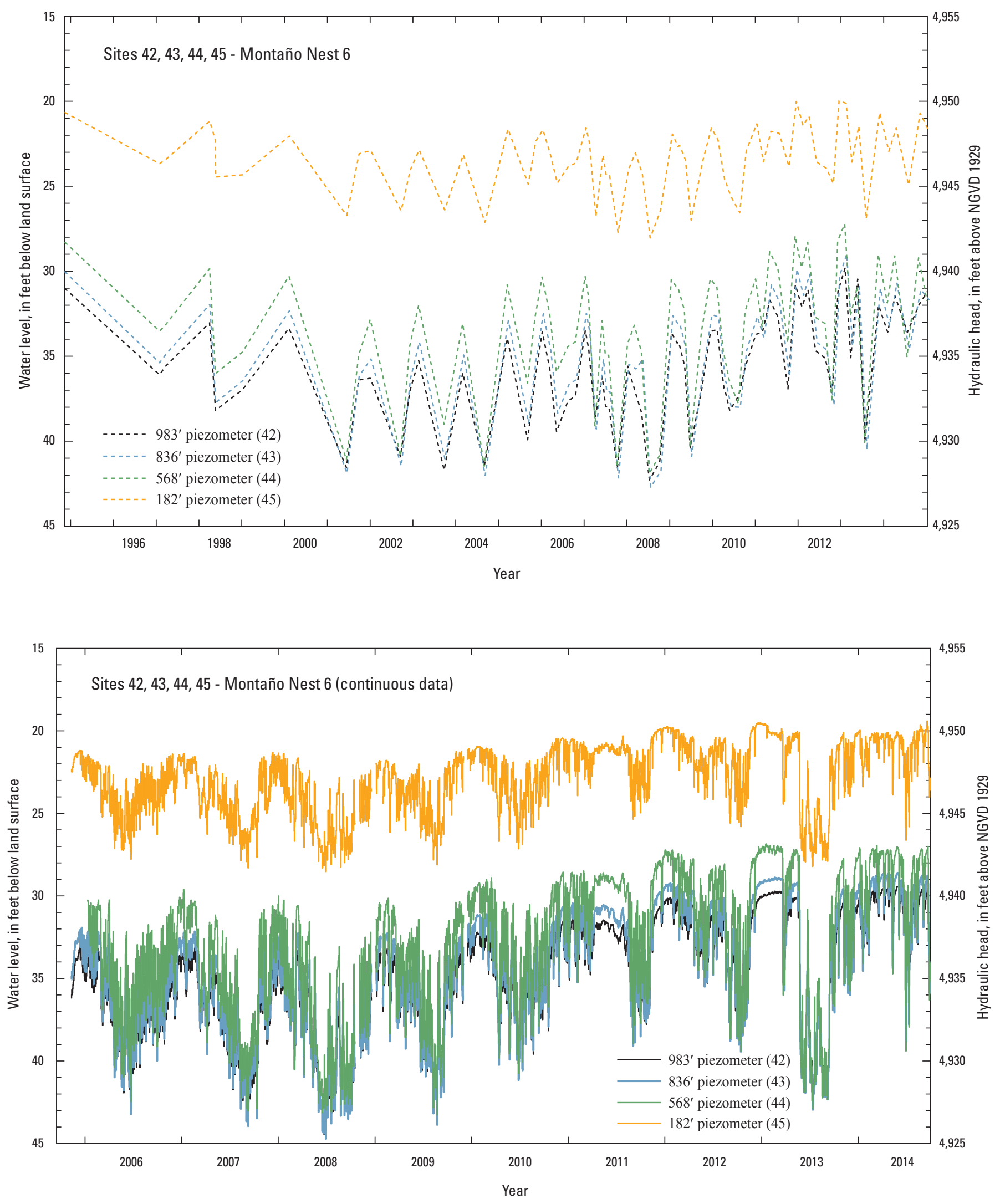

Figure 4. Water-level data for selected wells and piezometers in the Albuquerque Basin, central New Mexico (NGVD 29, National Geodetic Vertical Datum of 1929).-Continued 

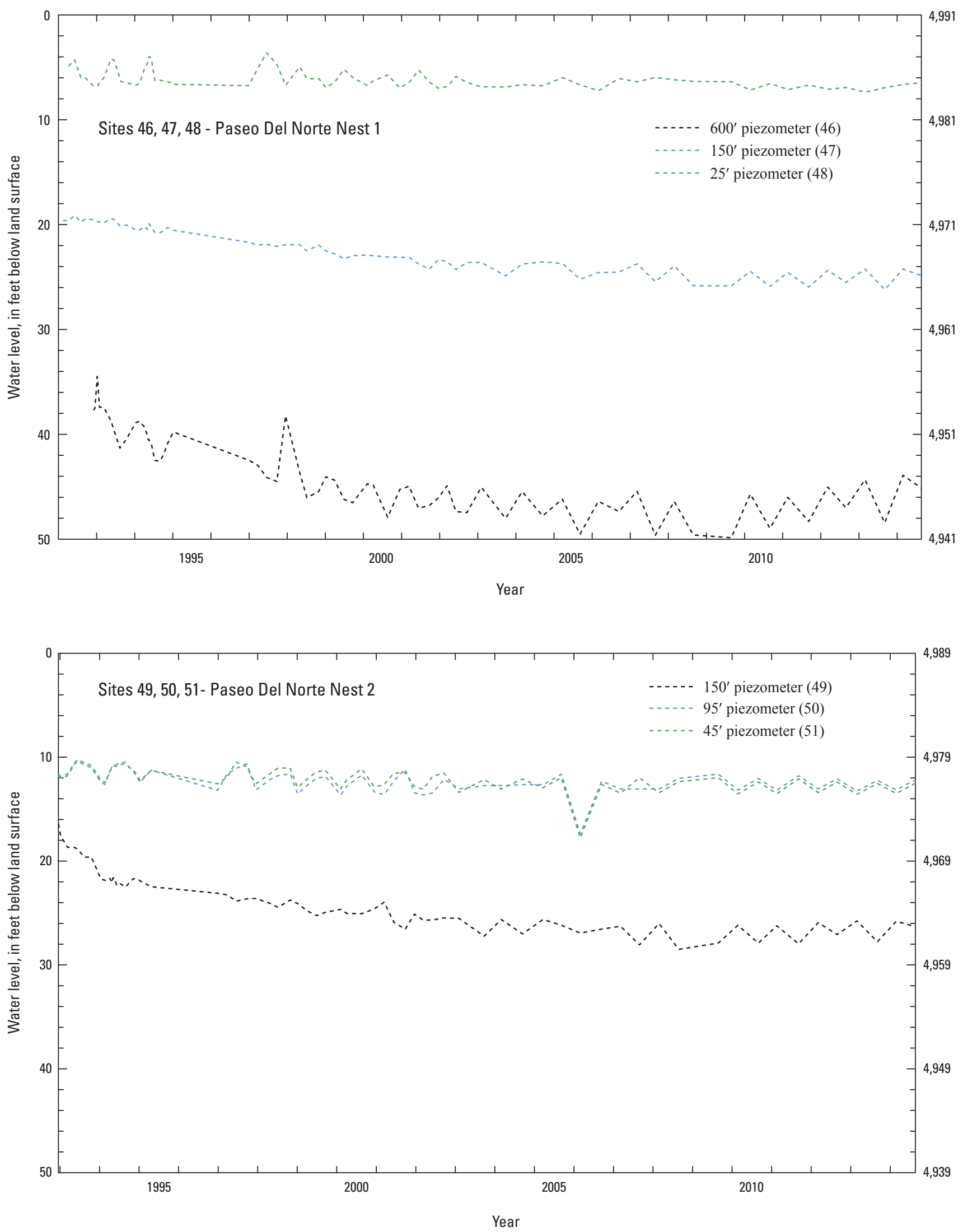

Figure 4. Water-level data for selected wells and piezometers in the Albuquerque Basin, central New Mexico (NGVD 29, National Geodetic Vertical Datum of 1929)._-Continued 

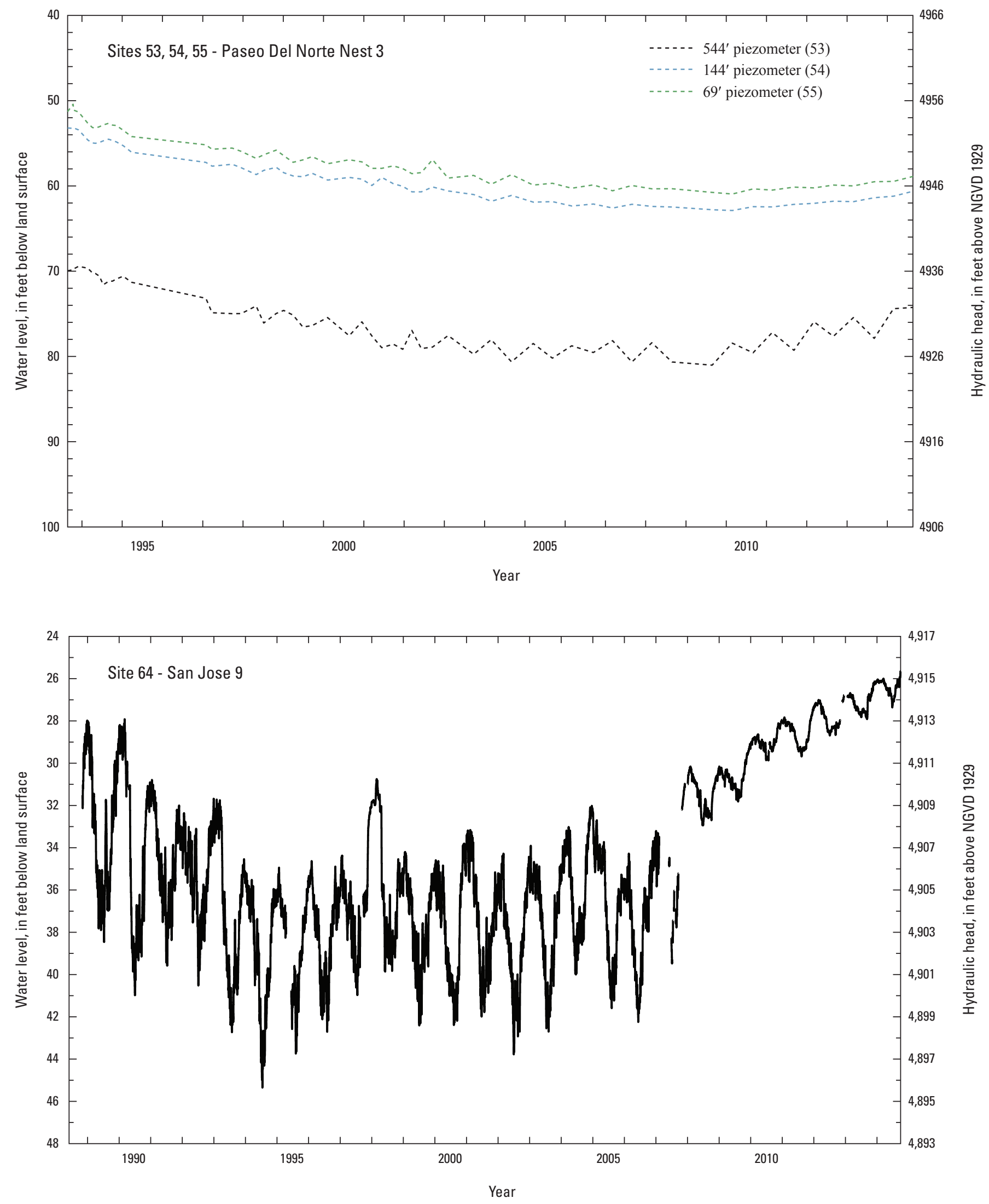

Figure 4. Water-level data for selected wells and piezometers in the Albuquerque Basin, central New Mexico (NGVD 29, National Geodetic Vertical Datum of 1929).-Continued 

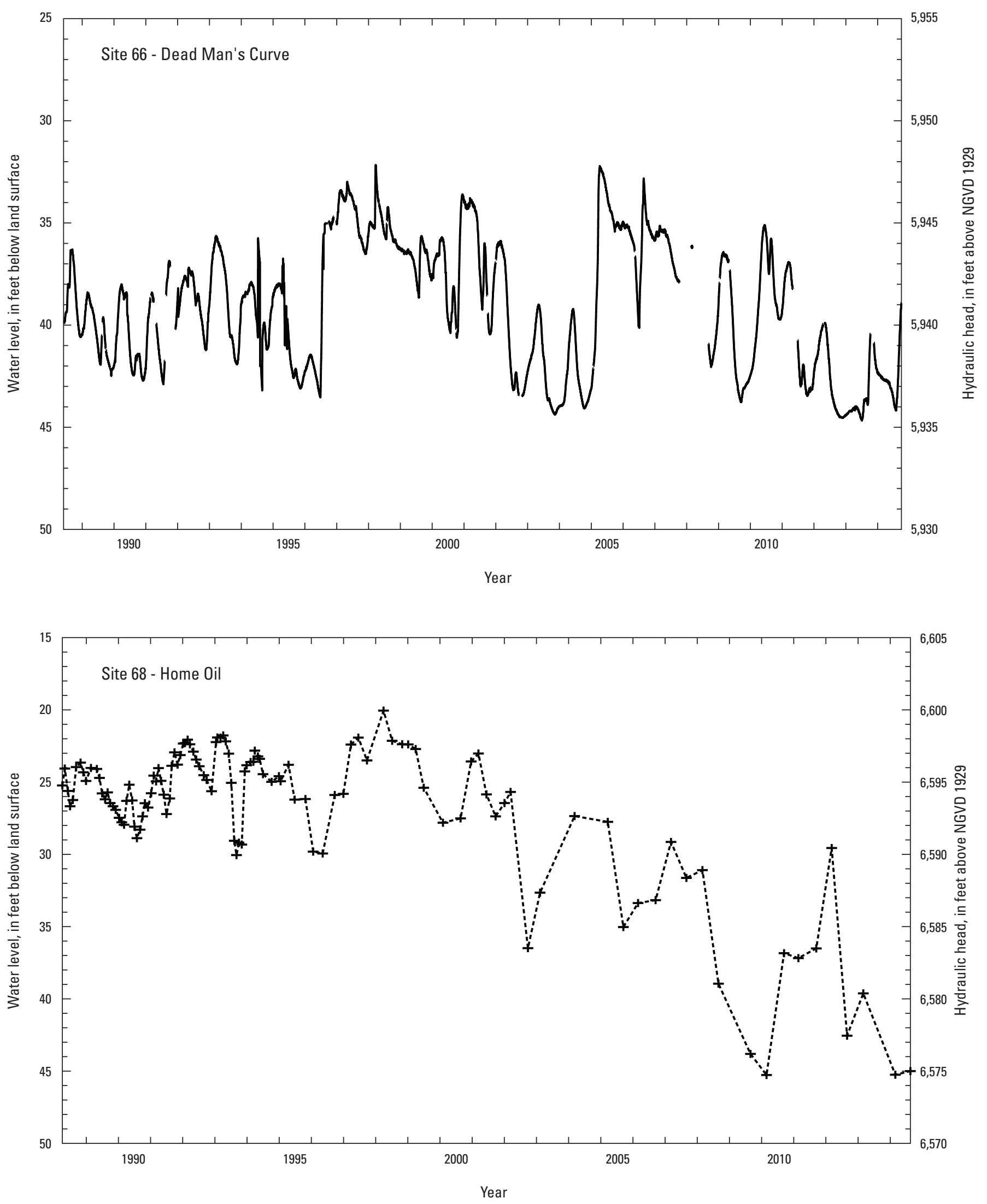

Figure 4. Water-level data for selected wells and piezometers in the Albuquerque Basin, central New Mexico (NGVD 29, National Geodetic Vertical Datum of 1929).-Continued 

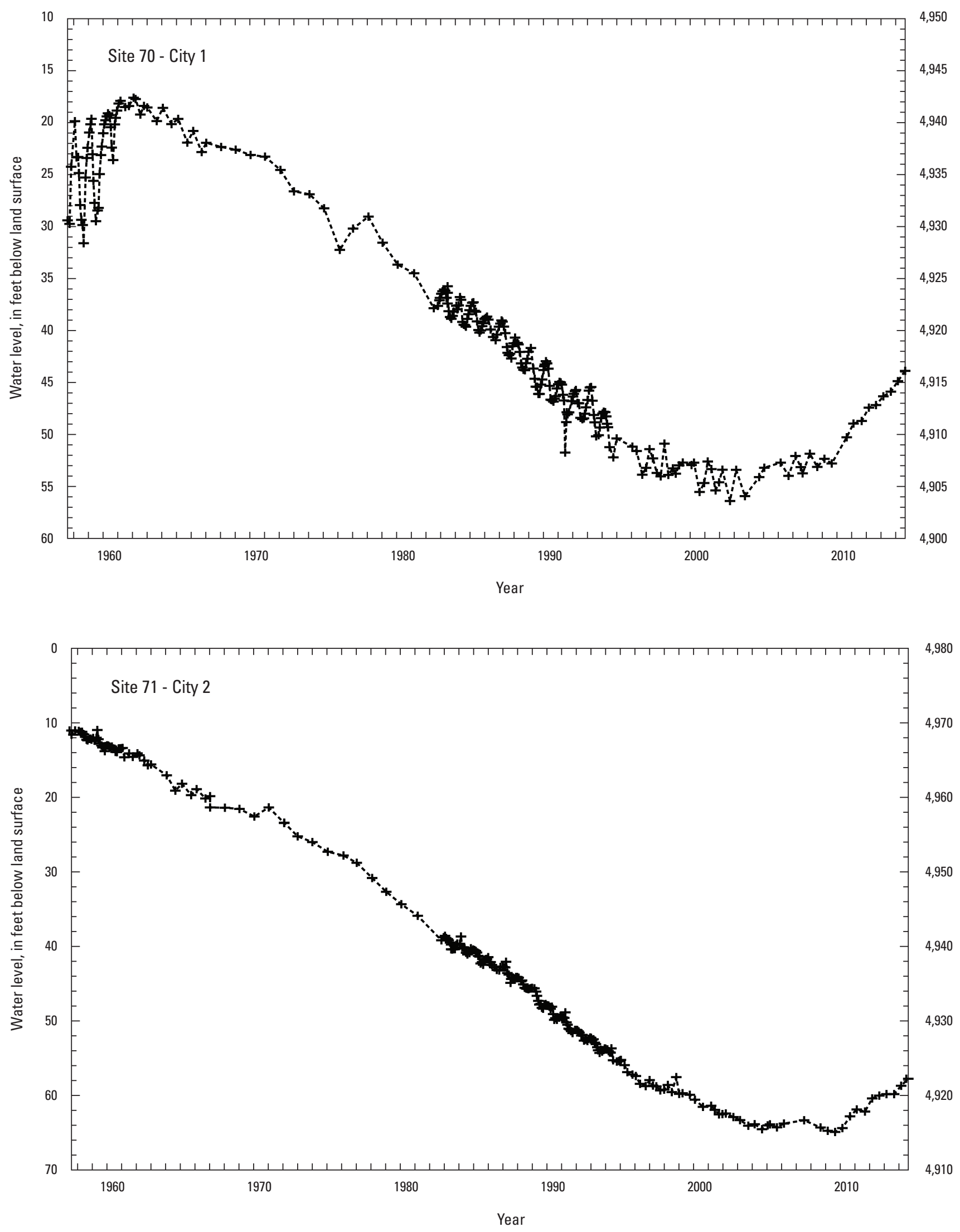

Figure 4. Water-level data for selected wells and piezometers in the Albuquerque Basin, central New Mexico (NGVD 29, National Geodetic Vertical Datum of 1929).-Continued 

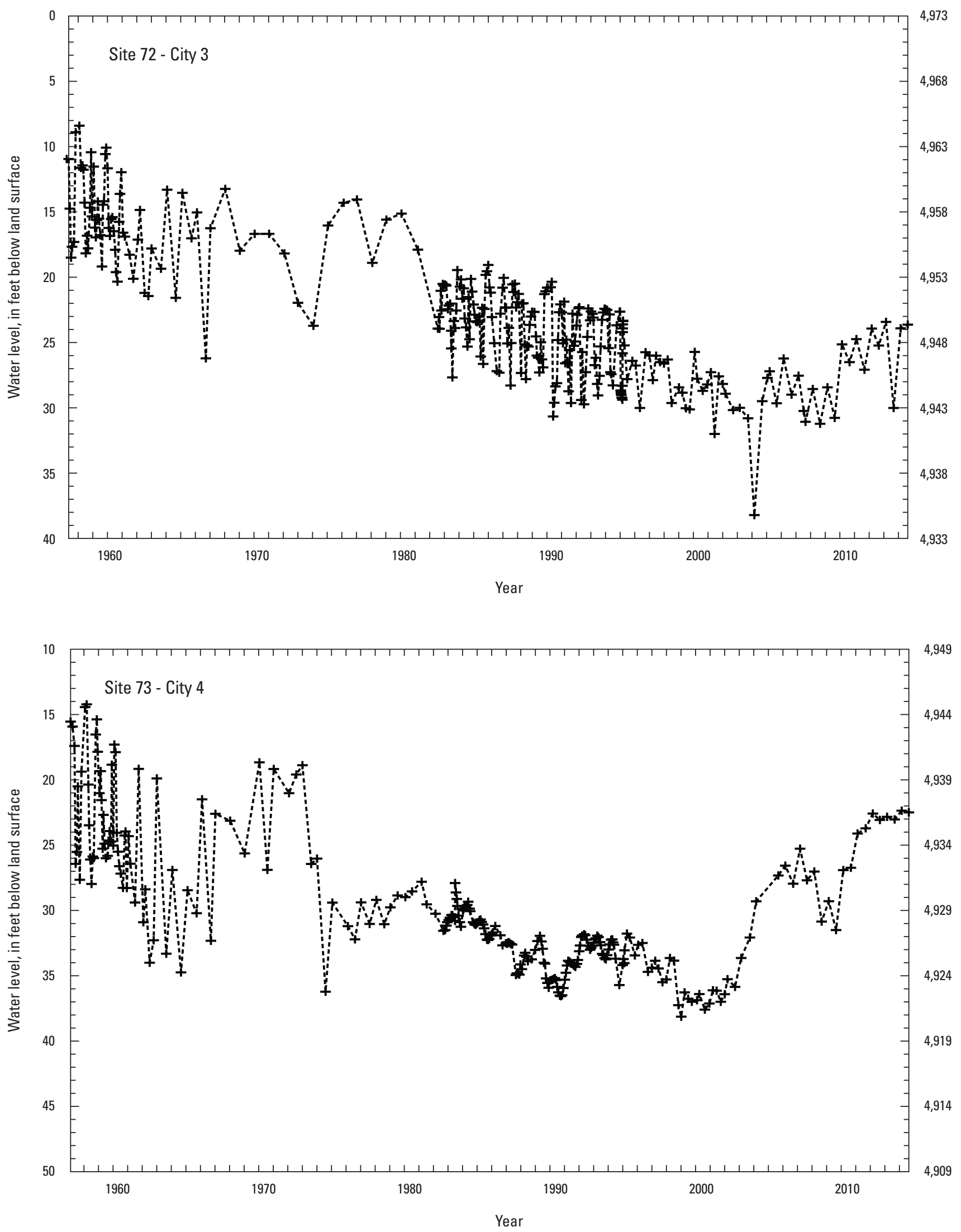

Figure 4. Water-level data for selected wells and piezometers in the Albuquerque Basin, central New Mexico (NGVD 29, National Geodetic Vertical Datum of 1929).-Continued 

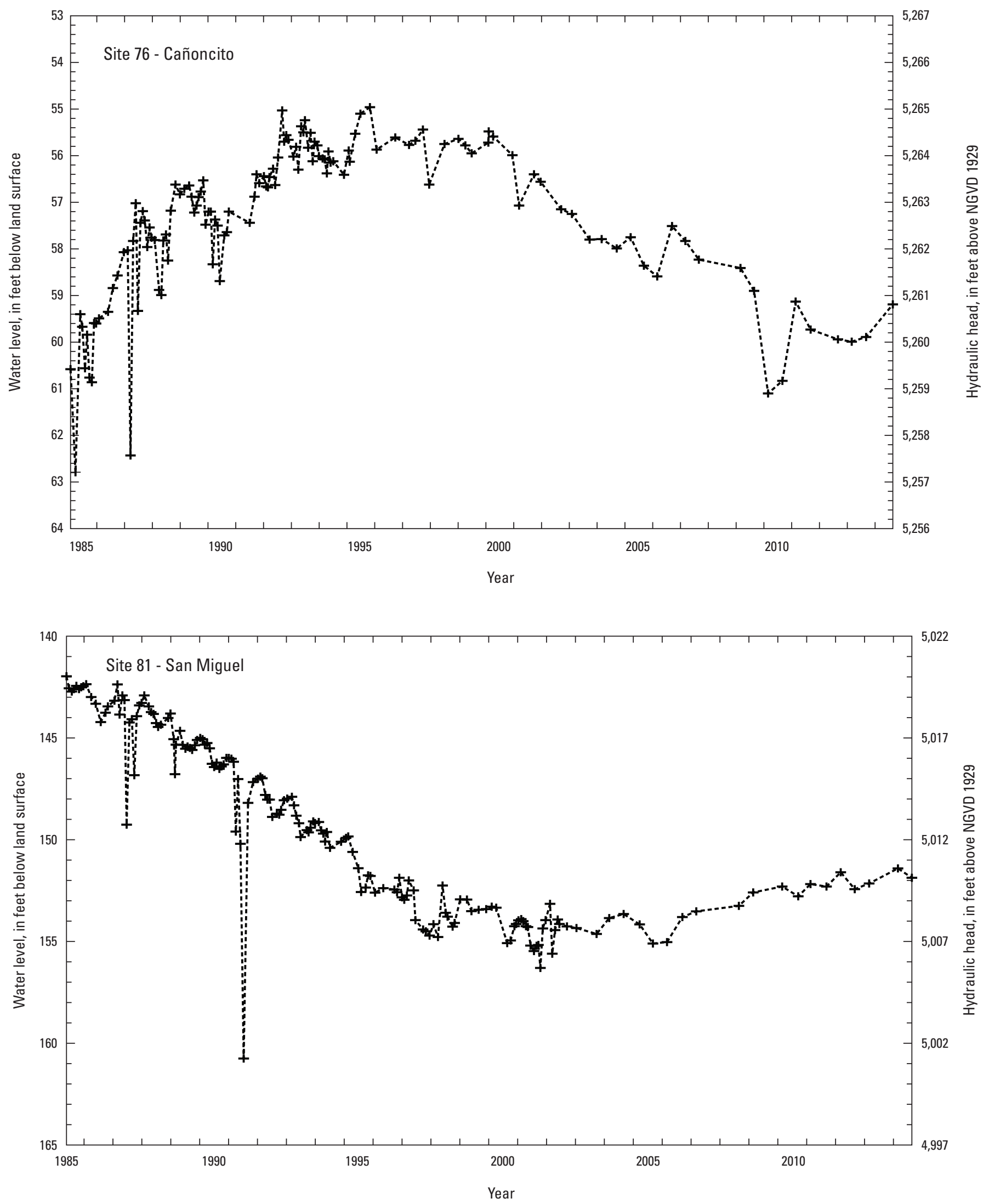

Figure 4. Water-level data for selected wells and piezometers in the Albuquerque Basin, central New Mexico (NGVD 29, National Geodetic Vertical Datum of 1929).-Continued 

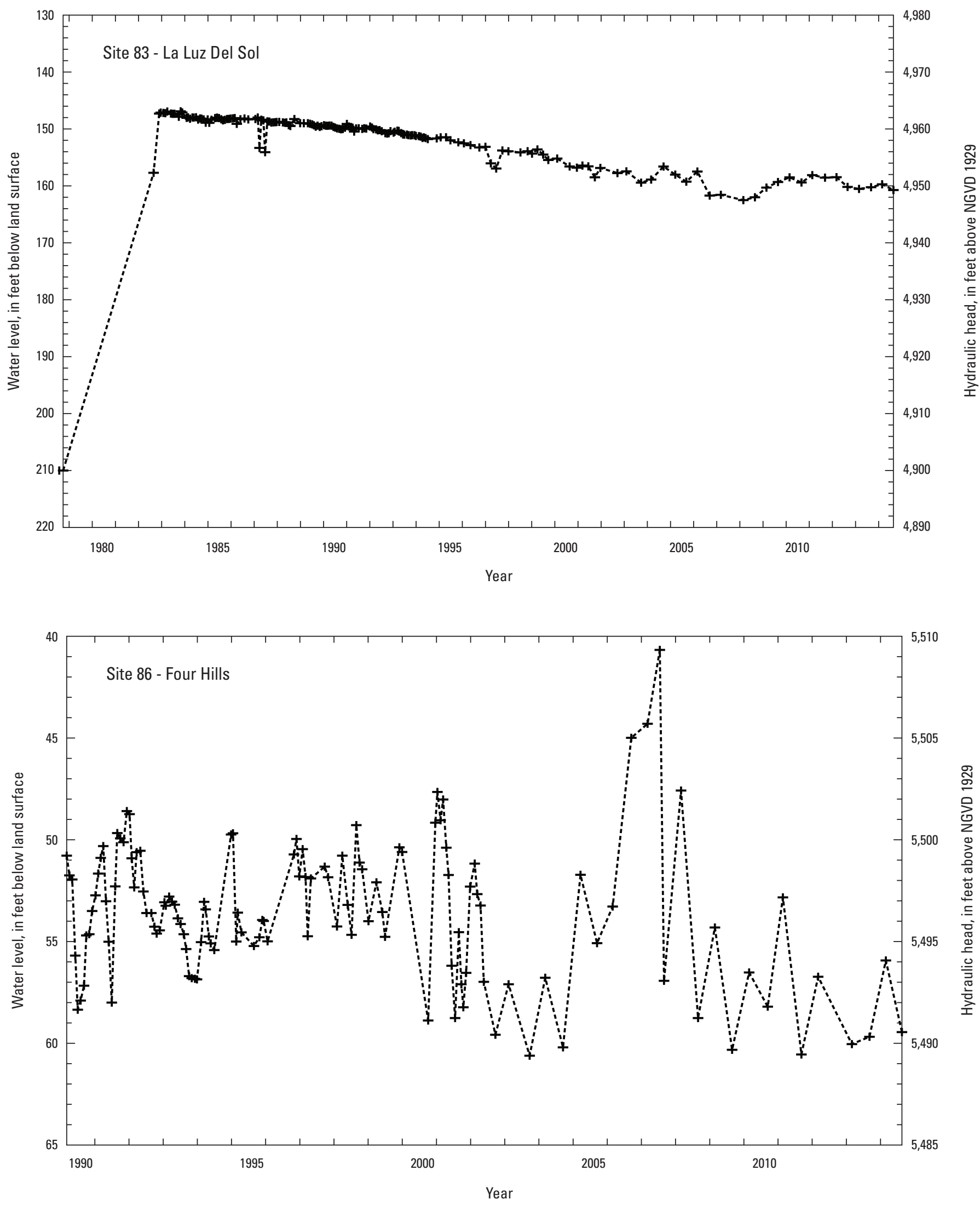

Figure 4. Water-level data for selected wells and piezometers in the Albuquerque Basin, central New Mexico (NGVD 29, National Geodetic Vertical Datum of 1929).-Continued 

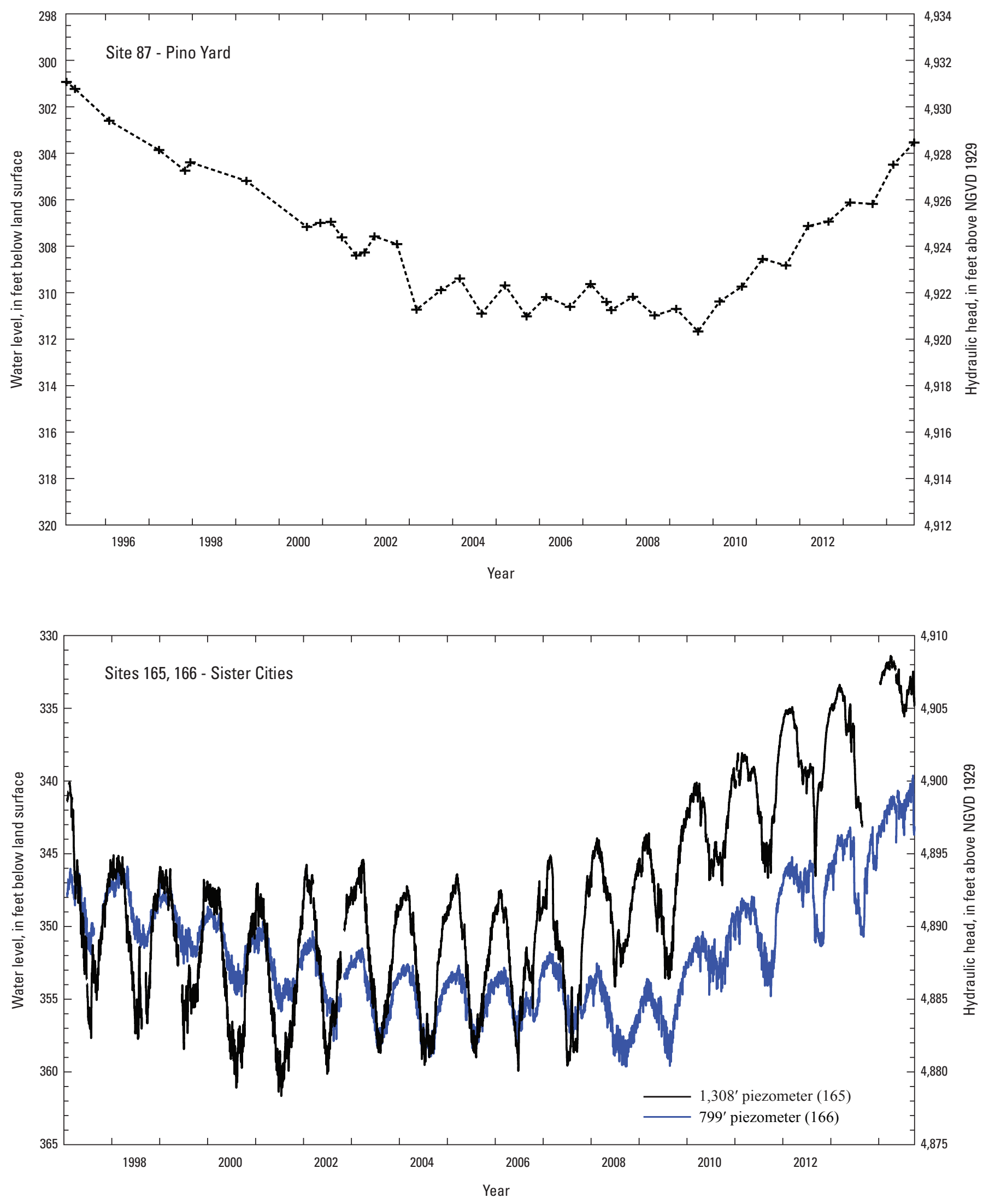

Figure 4. Water-level data for selected wells and piezometers in the Albuquerque Basin, central New Mexico (NGVD 29, National Geodetic Vertical Datum of 1929).-Continued 

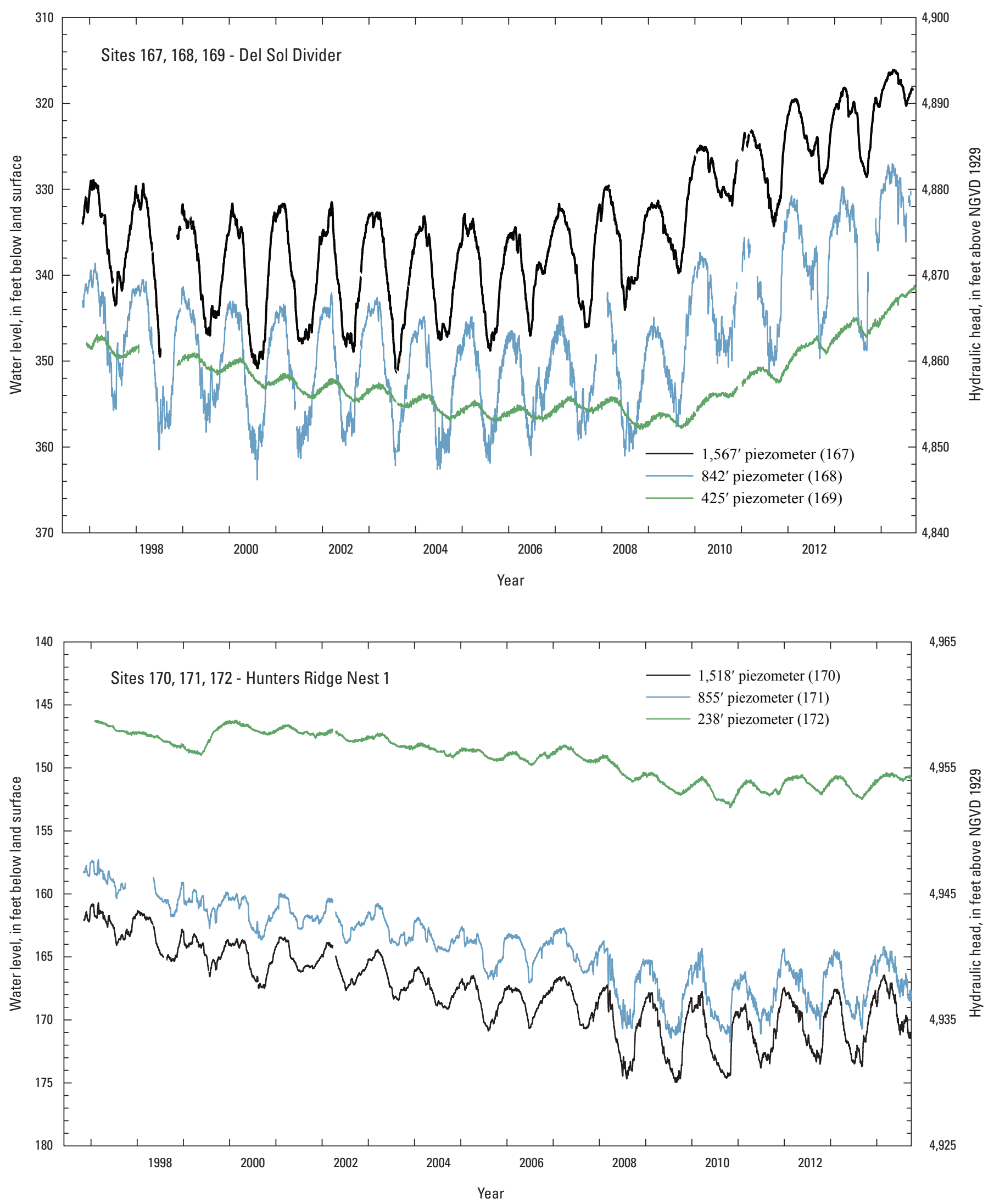

Figure 4. Water-level data for selected wells and piezometers in the Albuquerque Basin, central New Mexico (NGVD 29, National Geodetic Vertical Datum of 1929).-Continued 

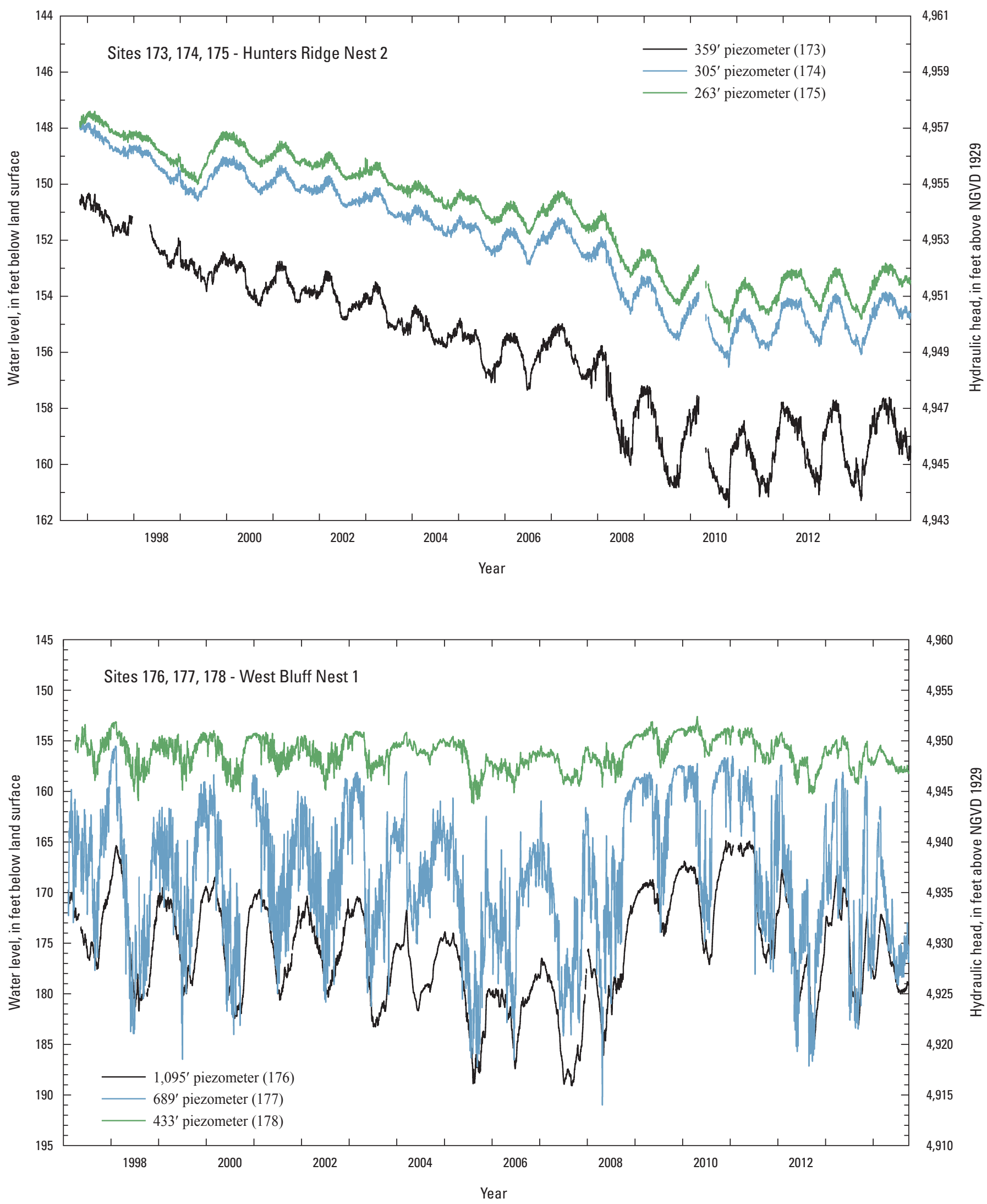

Figure 4. Water-level data for selected wells and piezometers in the Albuquerque Basin, central New Mexico (NGVD 29, National Geodetic Vertical Datum of 1929).-Continued 

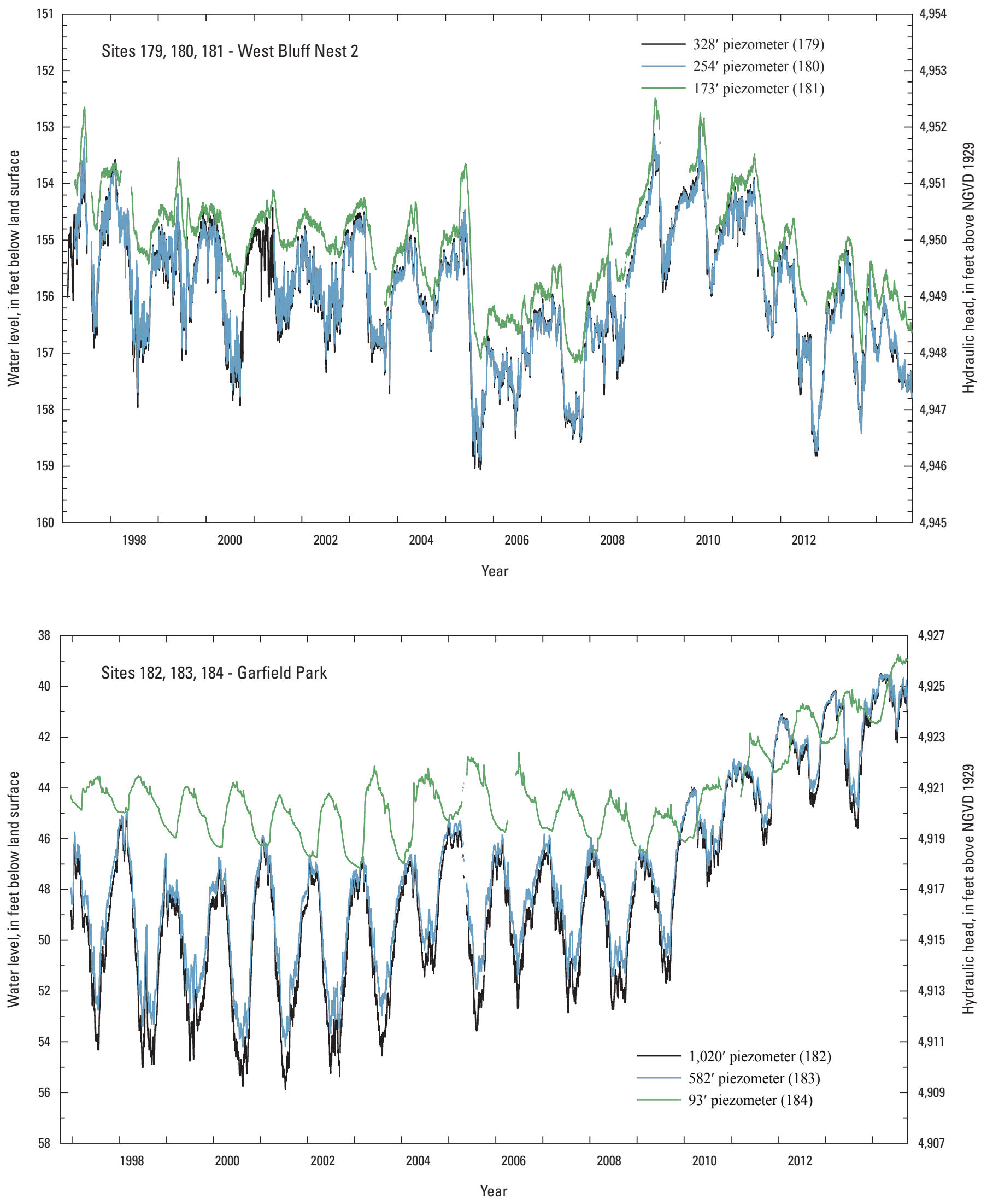

Figure 4. Water-level data for selected wells and piezometers in the Albuquerque Basin, central New Mexico (NGVD 29, National Geodetic Vertical Datum of 1929).-Continued 

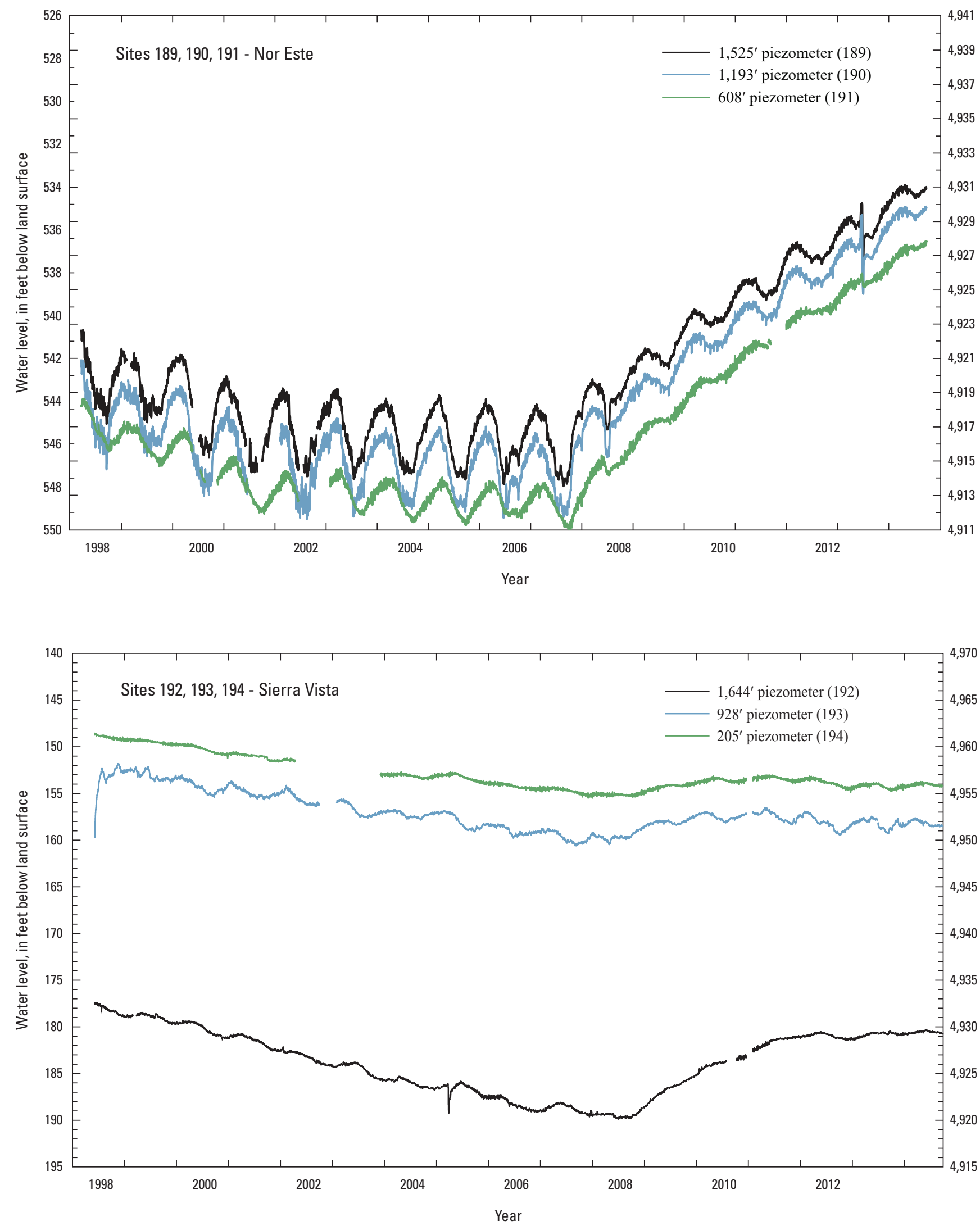

Figure 4. Water-level data for selected wells and piezometers in the Albuquerque Basin, central New Mexico (NGVD 29, National Geodetic Vertical Datum of 1929)._-Continued 

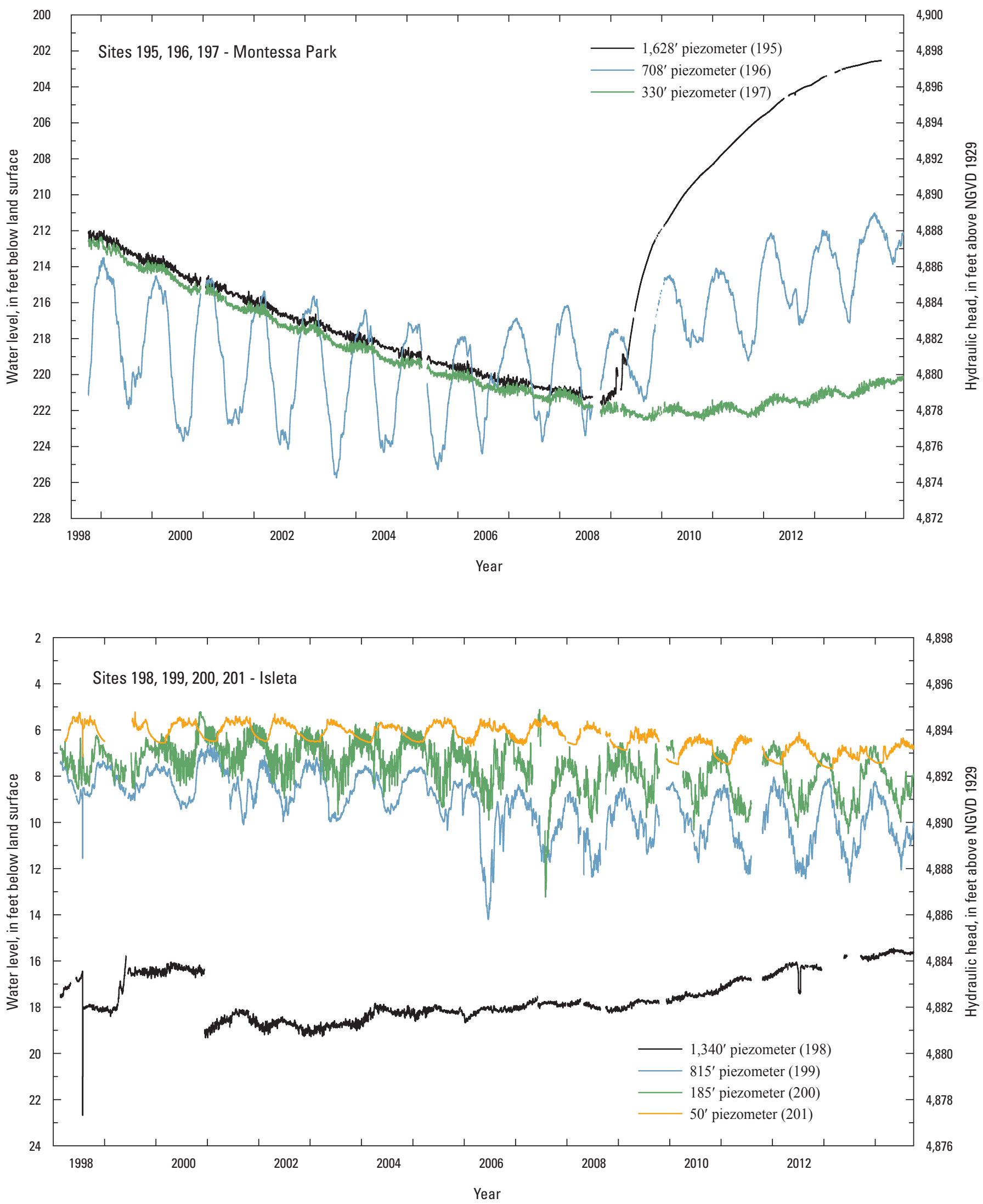

Figure 4. Water-level data for selected wells and piezometers in the Albuquerque Basin, central New Mexico (NGVD 29, National Geodetic Vertical Datum of 1929).-Continued 

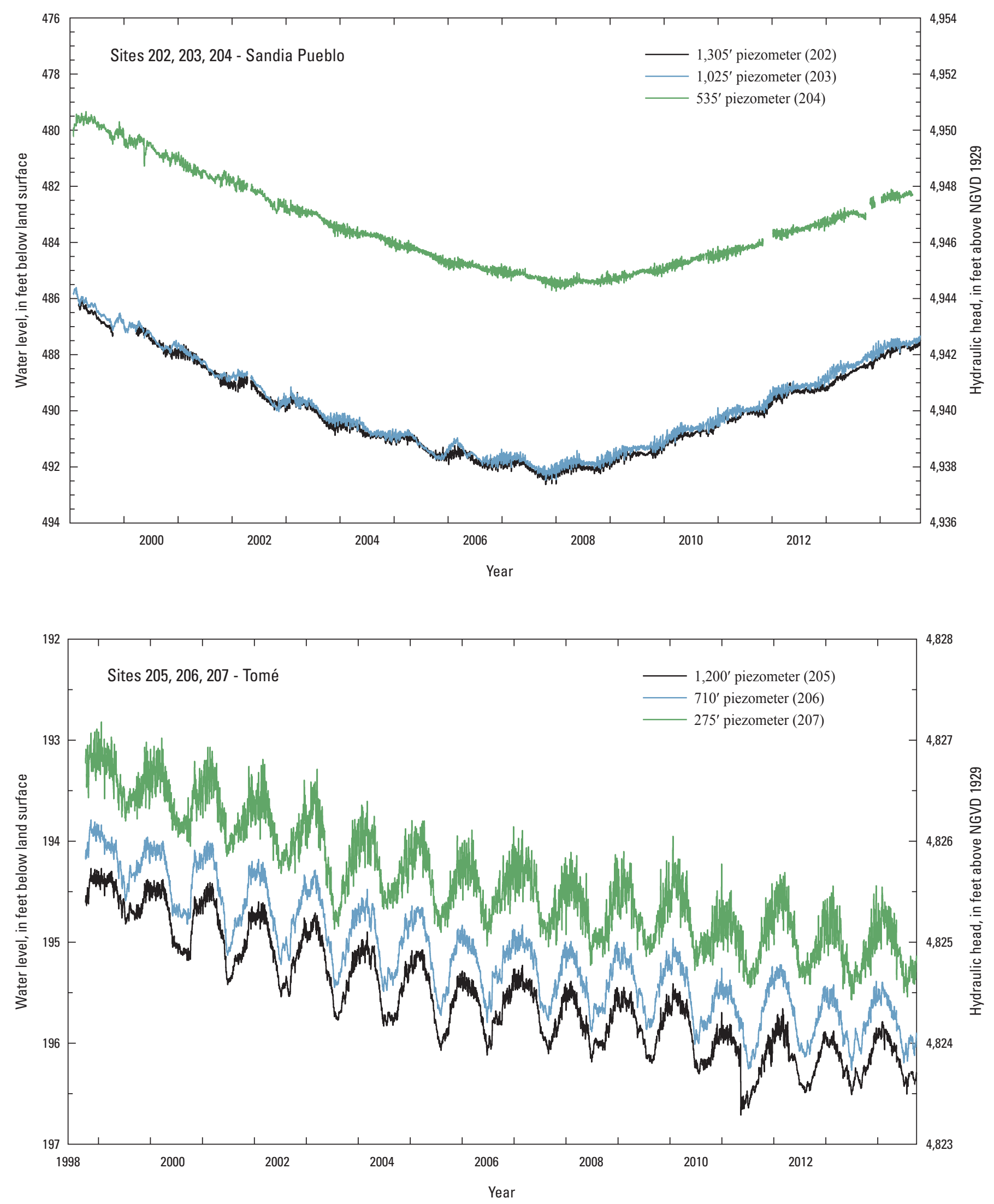

Figure 4. Water-level data for selected wells and piezometers in the Albuquerque Basin, central New Mexico (NGVD 29, National Geodetic Vertical Datum of 1929).-Continued 

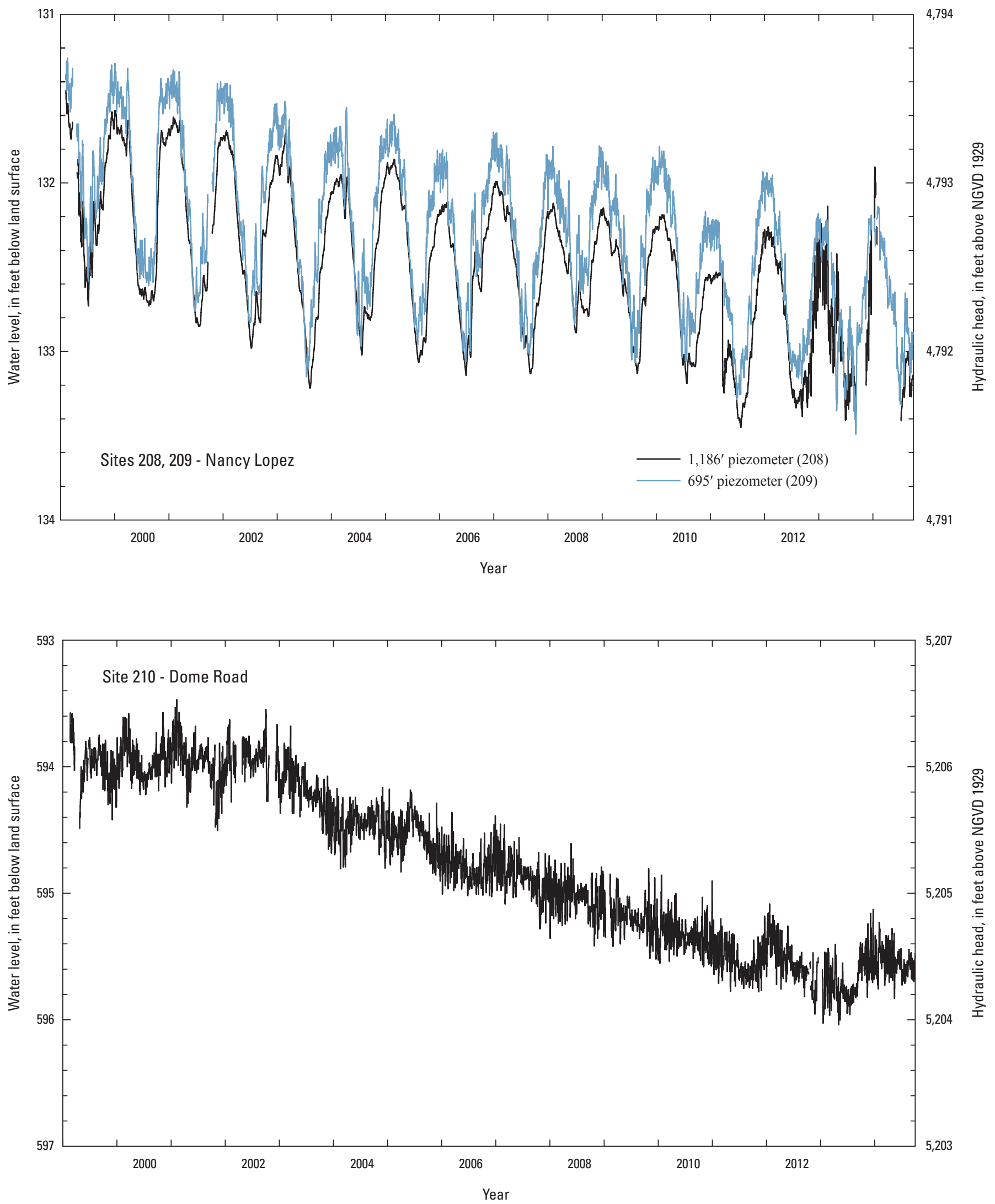

Figure 4. Water-level data for selected wells and piezometers in the Albuquerque Basin, central New Mexico (NGVD 29, National Geodetic Vertical Datum of 1929).-Continued 

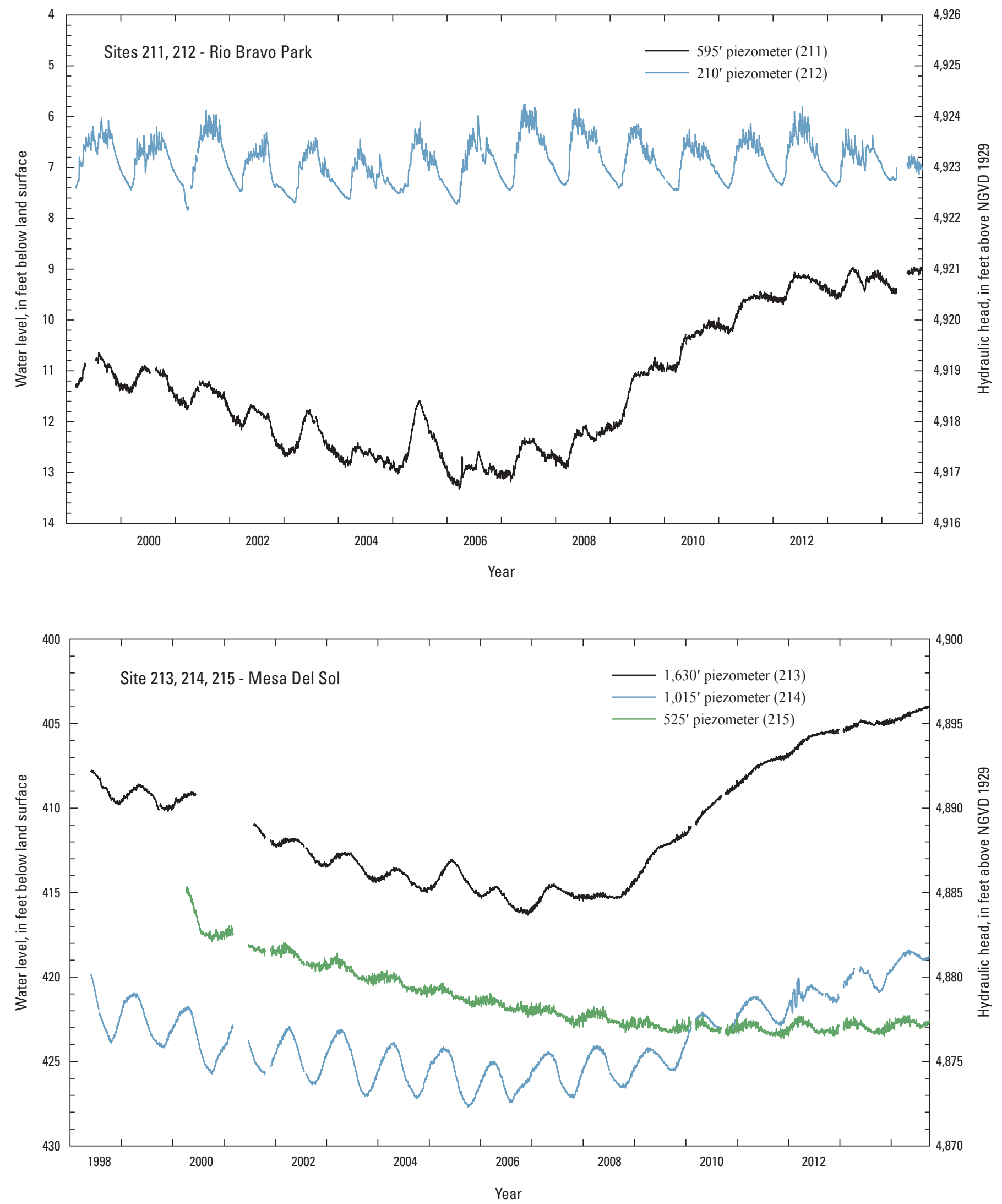

Figure 4. Water-level data for selected wells and piezometers in the Albuquerque Basin, central New Mexico (NGVD 29, National Geodetic Vertical Datum of 1929).-Continued 

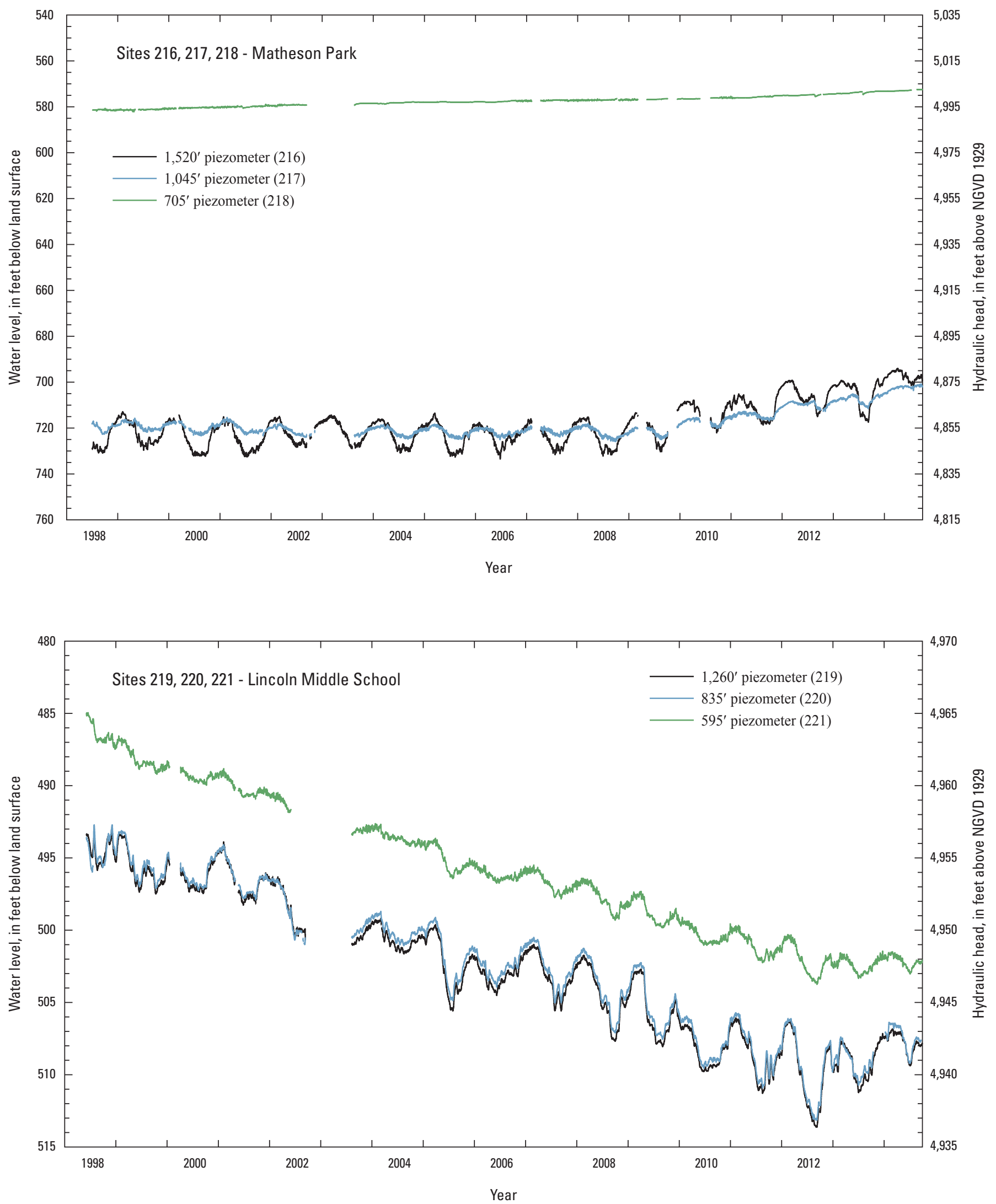

Figure 4. Water-level data for selected wells and piezometers in the Albuquerque Basin, central New Mexico (NGVD 29, National Geodetic Vertical Datum of 1929).-Continued 

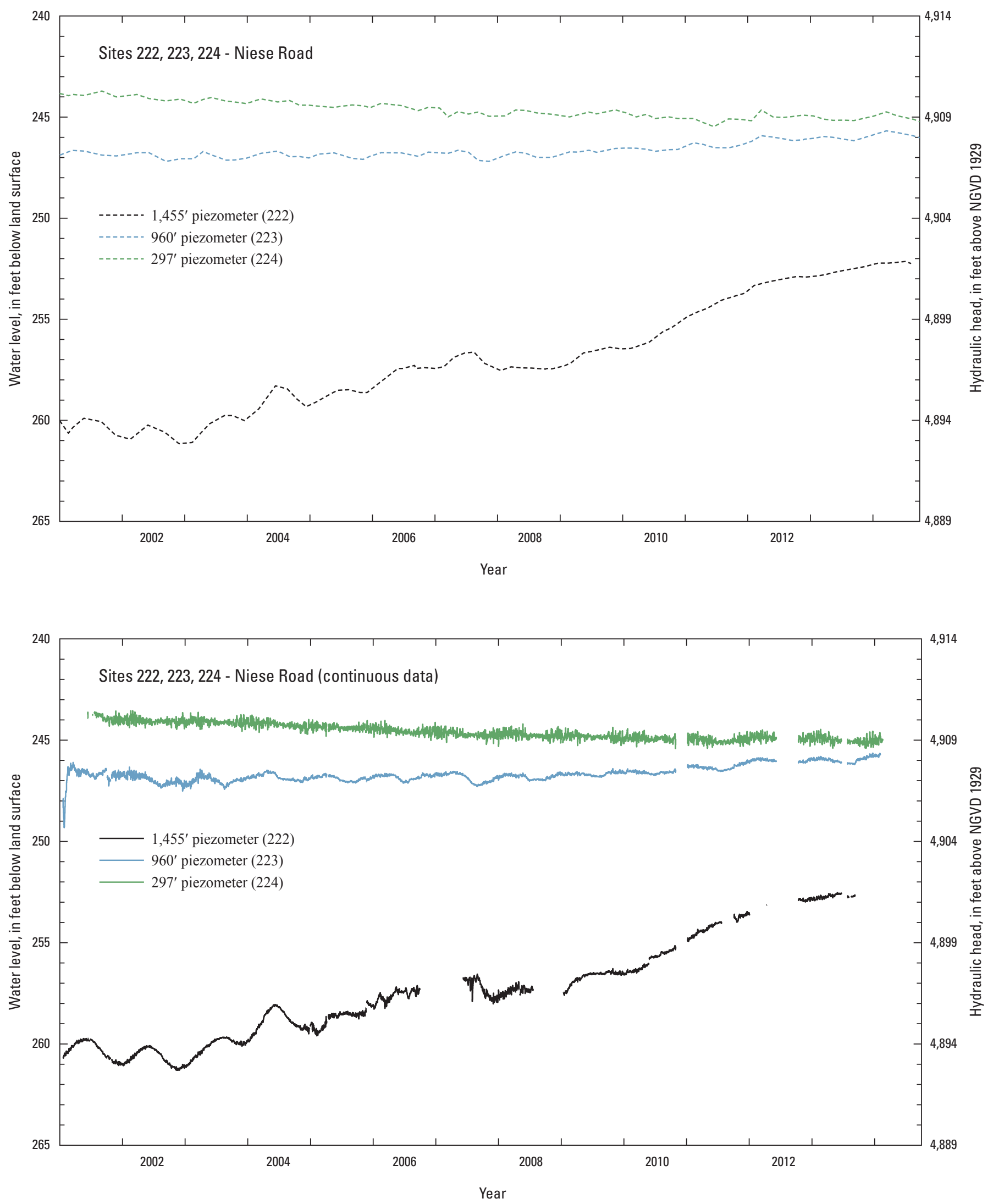

Figure 4. Water-level data for selected wells and piezometers in the Albuquerque Basin, central New Mexico (NGVD 29, National Geodetic Vertical Datum of 1929).-Continued 

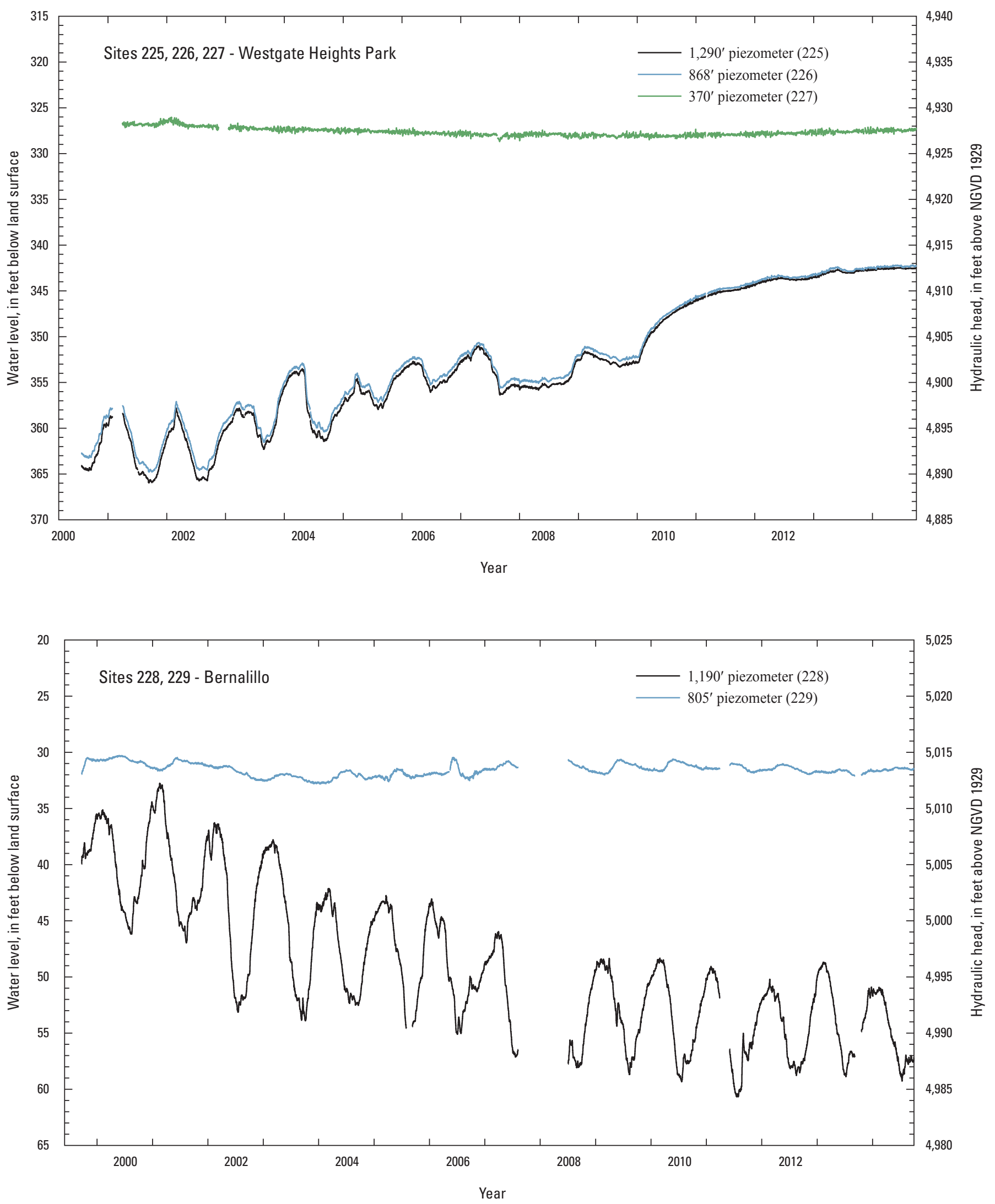

Figure 4. Water-level data for selected wells and piezometers in the Albuquerque Basin, central New Mexico (NGVD 29, National Geodetic Vertical Datum of 1929).-Continued 


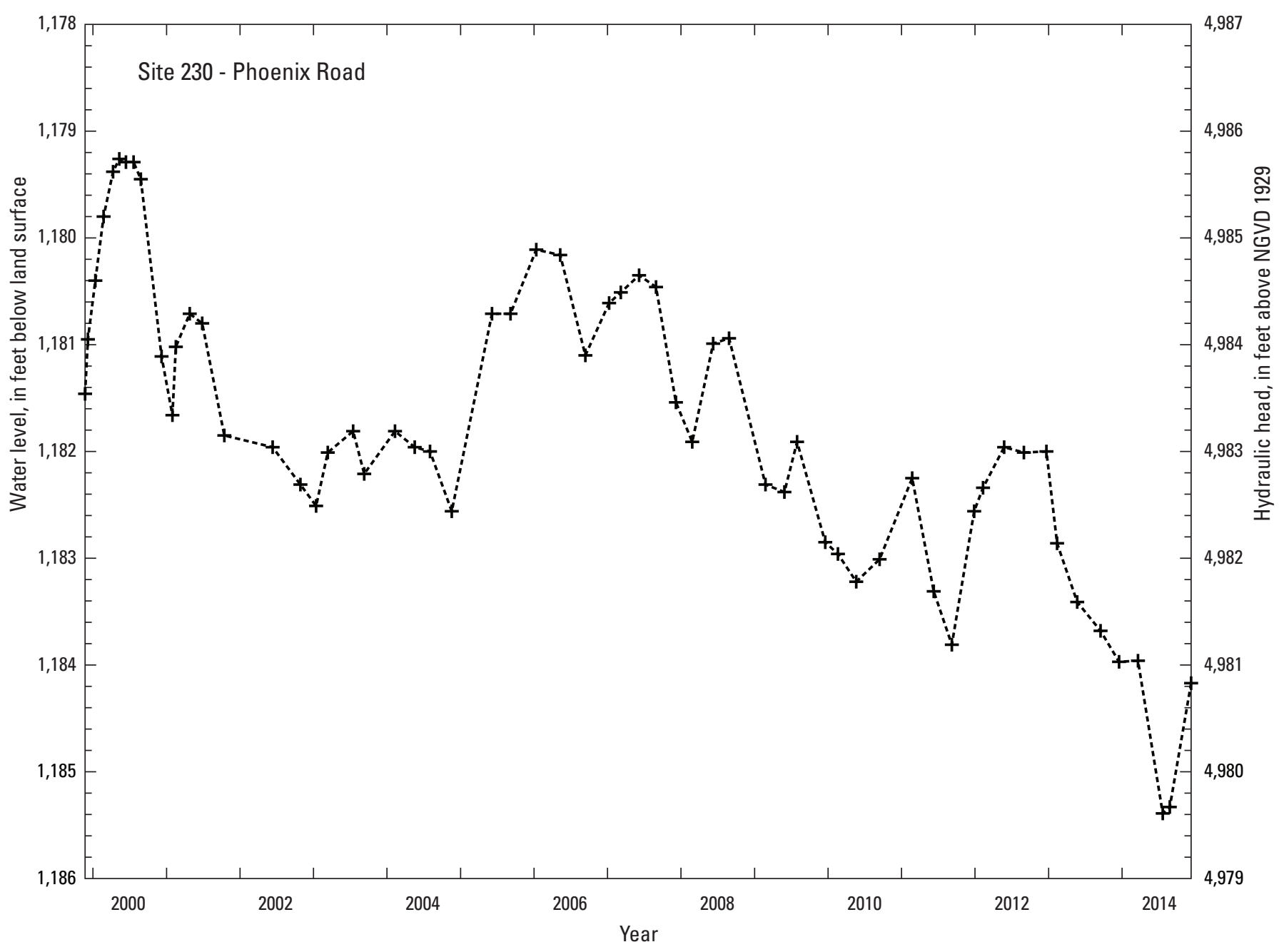

Figure 4. Water-level data for selected wells and piezometers in the Albuquerque Basin, central New Mexico (NGVD 29, National Geodetic Vertical Datum of 1929).-Continued 

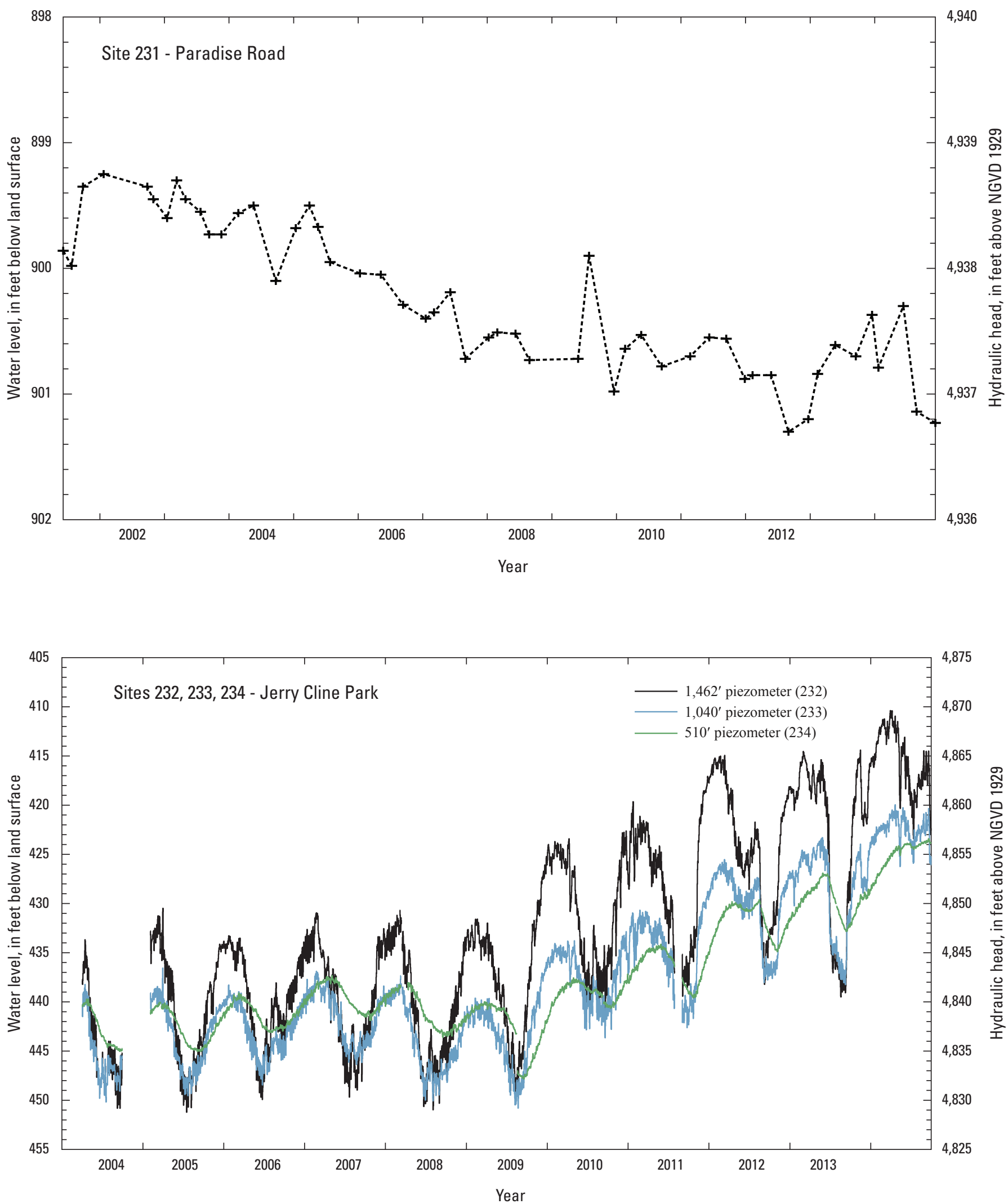

Figure 4. Water-level data for selected wells and piezometers in the Albuquerque Basin, central New Mexico (NGVD 29, National Geodetic Vertical Datum of 1929).-Continued 

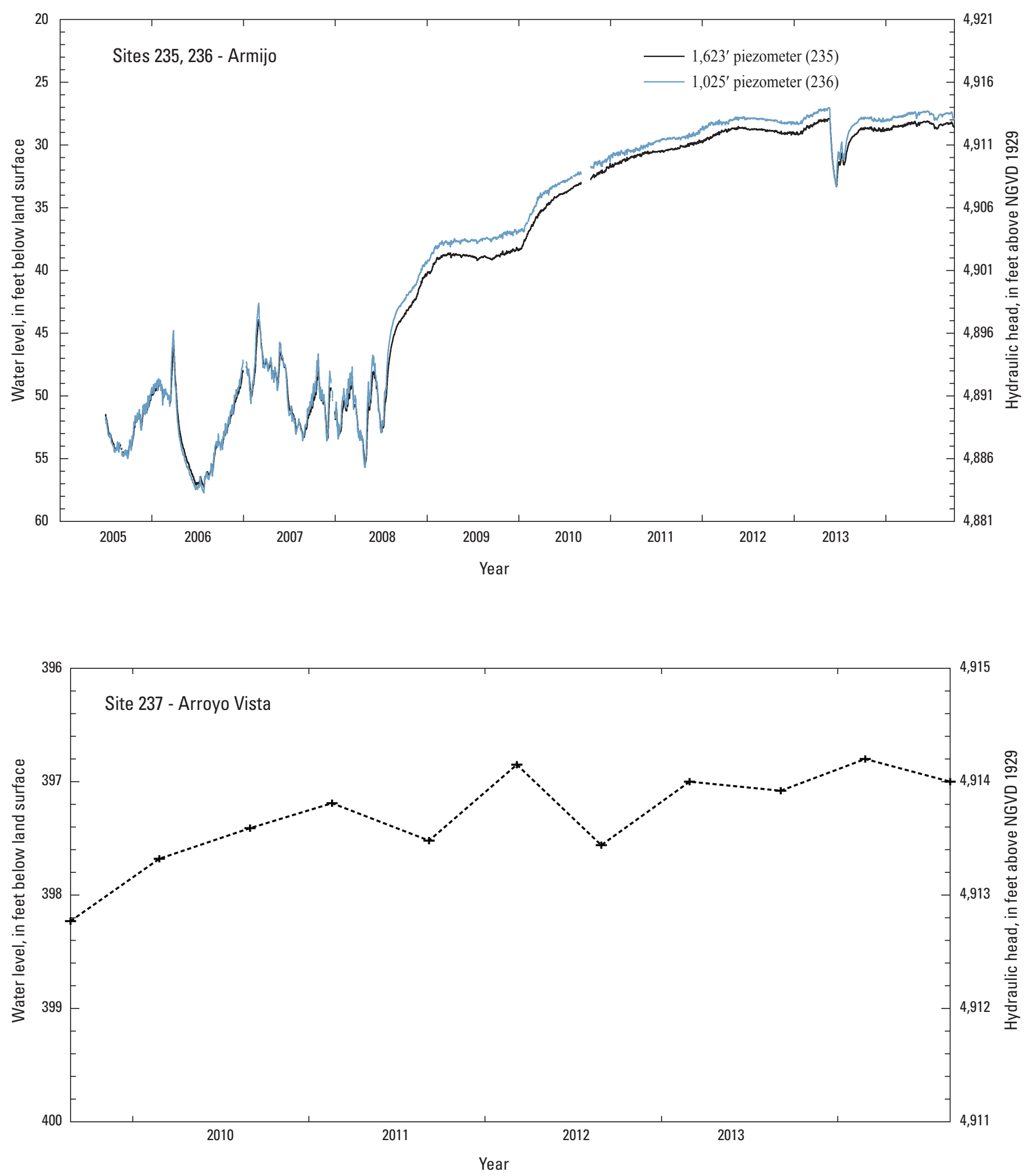

Figure 4. Water-level data for selected wells and piezometers in the Albuquerque Basin, central New Mexico (NGVD 29, National Geodetic Vertical Datum of 1929).-Continued 



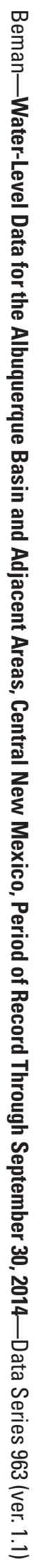

